





\section{University Chronicle}

VoL. I

SEPTEMBER, 1898

No. 4

\section{PHILOSOPHICAL CONCEPTIONS AND PRACTICAL RESULTS.*}

By William James.

An occasion like the present would seem to call for an absolutely untechnical discourse. I ought to speak of something connected with life rather than with logic. I ought to give a message with a practical outcome and an emotional musical accompaniment, so to speak, fitted to interest men as men, and yet also not altogether to disappoint philosophers-since philosophers, let them be as queer as they will, still are men in the secret recosses of their hearts, even here at Berkeley. I ought, I say, to produce something simple enough to catch and inspire the rest of you, and yet with just enough of ingenuity and oddity about it to keep the members of the Philosophical Union from yawning and letting their attention wander away.

I confess that I have something of this kind in my mind, a perfectly ideal discourse for the present occasion. Were I to set it down on paper, I verily believe it would be regarded by everyone as the final word of philosophy. It would bring theory down to a single point, at which every human being's practical life would begin. It would solve

* An address delivered before the Philosophical Union, at Berkeley, Angust 26, 1898, by William James, M.D., LL.D., Professor of Psychology in Harvard University. 
all the antinomies and contradictions, it would let loose all the right impulses and emotions; and everyone, on hearing it, would say, "Why, that is the truth! - that is what I have been believing, that is what I have really been living on all this time, but I never could find the words for it before. All that eludes, all that flickers and twinkles, all that invites and vanishes even whilst inviting, is here made a solidity and a possession. Here is the end of unsatisfactoriness, here the beginning of unimpeded clearness, joy, and power." Yes, my friends, I have such a discourse within me! But, do not judge me harshly, I cannot produce it on the present occasion. I humbly apologize; I have come across the continent to this wondrous Pacific Coast-to this Eden, not of the mythical antiquity, but of the solid future of mankind-I ought to give you something worthy of your hospitality, and not altogether unworthy of your great destiny, to help cement our rugged East and your wondrous West together in a spiritual bond,-and yet, and yet, and yet, I simply cannot. I have tried to articulate it, but it will not come. Philosophers are after all like poets. They are path-finders. What everyone can feel, what everyone can know in the bone and marrow of him, they sometimes can find words for and express. The words and thoughts of the philosophers are not exactly the words and thoughts of the poets-worse luck. But both alike have the same function. They are, if I may use a simile, so many spots, or blazes,-blazes made by the axe of the human intellect on the trees of the otherwise trackless forest of human experience. They give you somewhere to go from. They give you a direction and a place to reach. They do not give you the integral forest with all its sunlit glories and its moonlit witcheries and wonders. Ferny dells, and mossy waterfalls, and secret magic nooks escape you, owned only by the wild things to whom the region is a home. Happy they without the need of blazes! But to us the blazes give a sort of ownership. We can now use the forest, wend across it with companions, 
and enjoy its quality. It is no longer a place merely to get lost in and never return. The poet's words and the philosopher's phrases thus are helps of the most genuine sort, giving to all of us hereafter the freedom of the trails they made. Though they create nothing, yet for this marking and fixing function of theirs we bless their names and keep them on our lips, even whilst the thin and spotty and half-casual character of their operations is evident to our eyes.

No one like the path-finder himself feels the immensity of the forest, or knows the accidentality of his own trails. Columbus, dreaming of the ancient East, is stopped by poor pristine simple America, and gets no farther on that day; and the poets and philosophers themselves know as no one else knows that what their formulas express leaves unexpressed almost everything that they organically divine and feel. So I feel that there is a center in truth's forest where I have never been: to track it out and get there is the secret spring of all my poor life's philosophic efforts; at moments I almost strike into the final valley, there is a gleam of the end, a sense of certainty, but always there comes still another ridge, so my blazes merely circle towards the true direction; and although now, if ever, would be the fit occasion, yet I cannot take you to the wondrous hidden spot to-day. To-morrow it must be, or to-morrow, or to-morrow, and pretty surely death will overtake me ere the promise is fulfilled.

Of such postponed achievements do the lives of all philosophers consist. Truth's fullness is elusive; ever not quite, not quite! So we fall back on the preliminary blazes-a few formulas, a few technical conceptions, a few verbal pointers - which at least define the initial direction of the trail. And that to my sorrow, is all that I can do here at Berkeley to-day. Inconclusive I must be, and merely suggestive, though I will try to be as little technical as I can.

I will seek to define with you merely what seems to be the most likely direction in which to start upon the trail of 
truth. Years ago this direction was given to me by an American philosopher whose home is in the East, and whose published works, few as they are and scattered in periodicals, are no fit expression of his powers. I refer to Mr. Charles S. Peirce, with whose very existence as a philosopher I dare say many of you are unacquainted. $\mathrm{He}$ is one of the most original of contemporary thinkers; and the principle of practicalism-or pragmatism, as he called it, when I first heard him enunciate it at Cambridge in the early '70's-is the clue or compass by following which I find myself more and more confirmed in believing we may keep our feet upon the proper trail.

Peirce's principle, as we may call it, may be expressed in a variety of ways, all of them very simple. In the Popular Science Monthly for January, 1878, he introduces it as follows: The soul and meaning of thought, he says, can never be made to direct itself towards anything but the production of belief, belief being the demicadence which closes a musical phrase in the symphony of our intellectual life. Thought in movement has thus for its only possible motive the attainment of thought at rest. But when our thought about an object has found its rest in belief, then our action on the subject can firmly and safely begin. Beliefs, in short, are really rules for action; and the whole function of thinking is but one step in the production of habits of action. If there were any part of a thought that made no difference in the thought's practical consequences, then that part would be no proper element of the thought's significance. Thus the same thought may be clad in different words; but if the different words suggest no different conduct, they are mere outer accretions, and have no part in the thought's meaning. If, however, they determine conduct differently, they are essential elements of the significance. "Please open the door," and, "Veuillez ouvrir la porte," in French, mean just the same thing; but "D-n you, open the door," although in English, means something very different. Thus to develop a thought's 
meaning we need only determine what conduct it is fitted to produce; that conduct is for us its sole significance. And the tangible fact at the root of all our thought-distinctions, however subtle, is that there is no one of them so fine as to consist in anything but a possible difference of practice. To attain perfect clearness in our thoughts of an object, then, we need only consider what effects of a conceivably practical kind the object may involve-what sensations we are to expect from it, and what reactions we must prepare. Our conception of these effects, then, is for us the whole of our conception of the object, so far as that conception has positive significance at all.

This is the principle of Peirce, the principle of pragmatism. I think myself that it should be expressed more broadly than Mr. Peirce expresses it. The ultimate test for us of what a truth means is indeed the conduct it dictates or inspires. But it inspires that conduct because it first foretells some particular turn to our experience which shall call for just that conduct from us. And I should prefer for our purposes this evening to express Peirce's principle by saying that the effective meaning of any philosophic proposition can always be brought down to some particular consequence, in our future practical experience, whether active or passive; the point lying rather in the fact that the experience must be particular, than in the fact that it must be active.

To take in the importance of this principle, one must get accustomed to applying it to concrete cases. Such use as I am able to make of it convinces me that to be mindful of it in philosophical disputations tends wonderfully to smooth out misunderstandings and to bring in peace. If it did nothing else, then, it would yield a sovereignly valuable rule of method for discussion. So I shall devote the rest of this precious hour with you to its elucidation, because I sincerely think that if you once grasp it, it will shut your steps out from many an old false opening, and head you in the true direction for the trail. 
One of its first consequences is this. Suppose there are two different philosophical definitions, or propositions, or maxims, or what not, which seem to contradict each other, and about which men dispute. If, by supposing the truth of the one, you can foresee no conceivable practical consequence to anybody at any time or place, which is different from what you would foresee if you supposed the truth of the other, why then the difference between the two propositions is no difference,-it is only a specious and verbal difference, unworthy of further contention. Both formulas mean radically the same thing, although they may say it in such different words. It is astonishing to see how many philosophical disputes collapse into insignificance the moment you subject them to this simple test. There can be no difference which doesn't make a difference-no difference in abstract truth which does not express itself in a difference of concrete fact, and of conduct consequent upon the fact, imposed on somebody, somehow, somewhere, and somewhen. It is true that a certain shrinkage of values often seems to occur in our general formulas when we measure their meaning in this prosaic and practical way. They diminish. But the vastness that is merely based on vagueness is a false appearance of importance, and not a vastness worth retaining. The $x$ 's, $y$ 's, and $z$ 's always do shrivel, as I have heard a learned friend say, whenever at the end of your algebraic computation they change into so many plain $a^{\prime} \mathrm{s}, b$ 's, and $c^{\prime}$ 's; - but the whole function of algebra is, after all, to get them into that more definite shape; and the whole function of philosophy ought to be to find out what definite difference it will make to you and me, at definite instants of our life, if this world-formula or that world-formula be the one which is true.

If we start off with an impossible case, we shall perhaps all the more clearly see the use and scope of our principle. Let us, therefore, put ourselves, in imagination, in a position from which no forecasts of consequence, no dictates of conduct, can possibly be made, so that the principle of 
pragmatism finds no field of application. Let us, I mean, assume that the present moment is the absolutely last moment of the world, with bare nonentity beyond it, and no hereafter for either experience or conduct.

Now I say that in that case there would be no sense whatever in some of our most urgent and envenomed philosophical and religious debates. The question, "Is matter the producer of all things, or is a God there too?" would, for example, offer a perfectly idle and insignificant alternative if the world were finished and no more of it to come. Many of us, most of us, I think, now feel as if a terrible coldness and deadness would come over the world were we forced to believe that no informing spirit or purpose had to do with it, but it merely accidentally had come. The actually experienced details of fact might be the same on either hypothesis, some sad, some joyous; some rational, some odd and grotesque; but without a God behind them, we think they would have something ghastly, they would tell no genuine story, there would be no speculation in those eyes that they do glare with. With the God, on the other hand, they would grow solid, warm, and altogether full of real significance.

But I say that such an alternation of feelings, reasonable enough in a consciousness that is prospective, as ours now is, and whose world is partly yet to come, would be absolutely senseless and irrational in a purely retrospective consciousness summing up a world already past. For such a consciousness, no emotional interest could attach to the alternative. The problem would be purely intellectual; and if unaided matter could, with any scientific plausibility, be shown to cipher out the actual facts, then not the faintest shadow ought to cloud the mind, of regret for the God that by the same ciphering would prove needless and disappear from our belief.

For just consider the case sincerely, and say what would be the worth of such a God if he were there, with his work accomplished and his world run down. He would be worth 
no more than just that world was worth. To that amount of result, with its mixed merits and defects, his creative power could attain, but go no farther. And since there is to be no future; since the whole value and meaning of the world has been already paid in and actualized in the feelings that went with it in the passing, and now go with it in the ending; since it draws no supplemental significance (such as our real world draws) from its function of preparing something yet to come; why then, by it we take God's measure, as it were. $\mathrm{He}$ is the Being who could once for all do that; and for that much we are thankful to him, but for nothing more. But now, on the contrary hypothesis, namely, that the bits of matter following their "laws" could make that world and do no less, should we not be just as thankful to them? Wherein should we suffer loss, then, if we dropped God as an hypothesis and made the matter alone responsible? Where would the special deadness, "crassness," and ghastliness come in? And how, experience being what it is once for all, would God's presence in it make it any more "living," any richer in our sight?

Candidly, it is impossible to give any answer to this question. The actually experienced world is supposed to be the same in its details on either hypothesis, "the same, for our praise or blame," as Browning says. It stands there indefeasibly; a gift which can't be taken back. Calling matter the cause of it retracts no single one of the items that have made it up, nor does calling God the cause augment them. They are the God or the atoms, respectively, of just that and no other world. The God, if there, has been doing just what atoms could do-appearing in the character of atoms, so to speak-and earning such gratitude as is due to atoms, and no more. If his presence lends no different turn or issue to the performance, it surely can lend it no increase of dignity. Nor would indignity come to it were he absent, and did the atoms remain the only actors on the stage. When a play is once over, and the curtain down, you really make it no better by claiming an illustrious 
genius for its author, just as you make it no worse by calling him a common hack.

Thus if no future detail of experience or conduct is to be deduced from our hypothesis, the debate between materialism and theism becomes quite idle and insignificant. Matter and God in that event mean exactly the same thing-the power, namely, neither more nor less, that can make just this mixed, imperfect, yet completed world-and the wise man is he who in such a case would turn his back on such a supererogatory discussion. Accordingly most men instinctively-and a large class of men, the so-called positivists or scientists, deliberately-do turn their backs on philosophical disputes from which nothing in the line of definite future consequences can be seen to follow. The verbal and empty character of our studies is surely a reproach with which you of the Philosophical Union are but too sadly familiar. An escaped Berkeley student said to me at Harvard the other day-he had never been in the philosophical department here-"Words, words, words, are all that you philosophers care for." We philosophers think it all unjust; and yet, if the principle of pragmatism be true, it is a perfectly sound reproach unless the metaphysical alternatives under investigation can be shown to have alternative practical outcomes, however delicate and distant these may be. The common man and the scientist can discover no such outcomes. And if the metaphysician can discern none either, the common man and scientist certainly are in the right of it, as against him. His science is then but pompous trifling; and the endowment of a professorship for such a being would be something really absurd.

Accordingly, in every genuine metaphysical debate some practical issue, however remote, is really involved. To realize this, revert with me to the question of materialism or theism; and place yourselves this time in the real world we live in, the world that has a future, that is yet uncompleted whilst we speak. In this unfinished world 7 the alternative of "materialism or theism?" is intensely 
practical; and it is worth while for us to spend some minutes of our hour in seeing how truly this is the case.

How, indeed, does the programme differ for us, according as we consider that the facts of experience up to date are purposeless configurations of atoms moving according to eternal elementary laws, or that on the other hand they are due to the providence of God? As far as the past facts go, indeed there is no difference. These facts are in, are bagged, are captured; and the good that's in them is gained, be the atoms or be the God their cause. There are accordingly many materialists about us to-day who, ignoring altogether the future and practical aspects of the question, seek to eliminate the odium attaching to the word materialism, and even to eliminate the word itself, by showing that, if matter could give birth to all these gains, why then matter, functionally considered, is just as divine an entity as God, in fact coalesces with God, is what you mean by God. Cease, these persons advise us, to use either of these terms, with their outgrown opposition. Use terms free of the clerical connotations on the one hand; of the suggestion of grossness, coarseness, ignobility, on the other. Talk of the primal mystery, of the unknowable energy, of the one and only power, instead of saying either God or matter. This is the course to which Mr. Spencer urges us at the end of the first volume of his Psychology. In some well-written pages he there shows us that a "matter" so infinitely subtile, and performing motions as inconceivably quick and fine as modern science postulates in her explanations, has no trace of grossness

$\Gamma$ left. He shows that the conception of spirit, as we mortals hitherto have framed it, is itself too gross to cover the exquisite complexity of Nature's facts. Both terms, he says, are but symbols, pointing to that one unknowable $\checkmark$ reality in which their oppositions cease.

Throughout these remarks of Mr. Spencer, eloquent, and even noble in a certain sense, as they are, he seems to think that the dislike of the ordinary man to materialism 
comes from a purely æsthetic disdain of matter, as something gross in itself, and vile and despicable. Undoubtedly such an æsthetic disdain of matter has played a part in philosophic history. But it forms no part whatever of an intelligent modern man's dislikes. Give him a matter bound forever by its laws to lead our world nearer and nearer to perfection, and any rational man will worship that matter as readily as $\mathrm{Mr}$. Spencer worships his own so-called unknowable power. It not only has made for righteousness up to date, but it will make for righteousness forever; and that is all we need. Doing practically all that a God ean do, it is equivalent to God, its function is a God's function, and in a world in which a God would be superfluous; from such a world a God could never lawfully be missed.

But is the matter by which Mr. Spencer's process of cosmic evolution is carried on any such principle of neverending perfection as this? Indeed it is not, for the future end of every cosmically evolved thing or system of things is tragedy; and Mr. Spencer, in confining himself to the asthetic and ignoring the practical side of the controversy, has really contributed nothing serious to its relief. But apply now our principle of practical results, and see what a vital significance the question of materialism or theism immediately acquires.

Theism and materialism, so indifferent when taken retrospectively, point when we take them prospectively to wholly different practical consequences, to opposite outlooks of experience. For, according to the theory of $]$ mechanical evolution, the laws of redistribution of matter and motion, though they are certainly to thank for all the good hours which our organisms have ever yielded us and for all the ideals which our minds now frame, are yet fatally certain to undo their work again, and to redissolve everything that they have once evolved. You all know the picture of the last foreseeable state of the dead universe, as evolutionary science gives it forth. I cannot 
state it better than in Mr. Balfour's words: "The energies of our system will decay, the glory of the sun will be dimmed, and the earth, tideless and inert, will no longer tolerate the race which has for a moment disturbed its solitude. Man will go down into the pit, and all his thoughts will perish. The uneasy consciousness which in this obscure corner has for a brief space broken the contented silence of the universe, will be at rest. Matter will know itself no longer. 'Imperishable monuments' and 'immortal deeds,' death itself, and love stronger than death, will be as if they had not been. Nor will anything that is, be better or worse for all that the labor, genius, devotion, and suffering of man have striven through countless ages to effect."*

That is the sting of it, that in the vast driftings of the cosmic weather, though many a jewelled shore appears, and many an enchanted cloud-bank floats away, long lingering ere it be dissolved-even as our world now lingers, for our joy-yet when these transient products are gone, nothing, absolutely nothing remains, to represent those particular qualities, those elements of preciousness which they may have enshrined. Dead and gone are they, gone utterly from the very sphere and room of being. Without an echo; without a memory; without an influence on aught that may come after, to make it care for similar ideals. This utter final wreck and tragedy is of the essence of scientific materialism as at present understood. The lower and not the higher forces are the eternal forces, or the last surviving forces within the only cycle of evolution which we can definitely see. Mr. Spencer believes $\Gamma$ this as much as anyone; so why should he argue with us as if we were making silly æsthetic objections to the "grossness" of "matter and motion,"-the principles of his philosophy,-when what really dismays $u$ s in it is the $\checkmark$ disconsolateness of its ulterior practical results?

No, the true objection to materialism is not positive but

*The Foundations of Belief, p. 30. 
negative. It would be farcical at this day to make complaint of it for what it is, for "grossness." Grossness is what grossness does-we now know that. We make com-7 plaint of it, on the contrary, for what it is not-not a permanent warrant for our more ideal interests, not a fulfiller of our remotest hopes.

The notion of God, on the other hand, however inferior it may be in clearness to those mathematical notions so current in mechanical philosophy, has at least this practical superiority over them, that it guarantees an ideal order that shall be permanently preserved. A world with a God in it to say the last word, may indeed burn up or freeze, but we then think of Him as still mindful of the old ideals and sure to bring them elsewhere to fruition; so that, where $\mathrm{He}$ is, tragedy is only provisional and partial, and shipwreck and dissolution not the absolutely final things. This need of an eternal moral order is one of the deepest $X$ needs of our breast. And those poets, like Dante and Wordsworth, who live on the conviction of such an order, owe to that fact the extraordinary tonic and consoling power of their verse. Here then, in these different emotional and practical appeals, in these adjustments of our concrete attitudes of hope and expectation, and all the delicate consequences which their differences entail, lie the real meanings of materialism and theism-not in hairsplitting abstractions about matter's inner essence, or about the metaphysical attributes of God. Materialism means simply the denial that the moral order is eternal, and the cutting off of ultimate hopes; theism means the affirmation of an eternal moral order and the letting loose of hope. Surely here is an issue genuine enough, for anyone who feels it; and, as long as men are men, it will yield matter for serious philosophic debate. Concerning this question, at any rate, the positivists and pooh-pooh-ers of metaphysics are in the wrong.

But possibly some of you may still rally to their defense. Even whilst admitting that theism and materialism make 
different prophecies of the world's future, you may yourselves pooh-pooh the difference as something so infinitely remote as to mean nothing for a sane mind. The essence Cof a sane mind, you may say, is to take shorter views, and to feel no concern about such chimæras as the latter end of the world. Well, I can only say that if you say this, you do injustice to human nature. Religious melancholy is not disposed of by a simple flourish of the word insanity. The absolute things, the last things, the overlapping things, are 「 the truly philosophic concern; all superior minds feel seriously about them, and the mind with the shortest views is simply the mind of the more shallow man.

However, I am willing to pass over these very distant outlooks on the ultimate, if any of you so insist. The theistic controversy can still serve to illustrate the principle of pragmatism for us well enough, without driving us so far

rafield. If there be a God, it is not likely that he is confined solely to making differences in the world's latter end; he probably makes differences all along its course. Now the principle of practicalism says that the very meaning of the conception of God lies in those differences which must be made in our experience if the conception be true. God's famous inventory of perfections, as elaborated by dogmatic theology, either means nothing, says our principle, or it implies certain definite things that we can feel and do at particular moments of our lives, things which we could not feel and should not do were no God present and were the business of the universe carried on by material atoms instead. So far as our conceptions of the Deity involve no such experiences, so far they are meaningless and verbal,scholastic entities and abstractions, as the positivists say, and fit objects for their scorn. But so far as they do involve such definite experiences, God means something for us, and may be real.

Now if we look at the definitions of God made by dogmatic theology, we see immediately that some stand and some fall when treated by this test. God, for example, 
as any orthodox text-book will tell us, is a being existing not only per se, or by himself, as created beings exist, but $a$ se, or from himself; and out of this "aseity" flow most of his perfections. $\mathrm{He}$ is, for example, necessary; absolute; infinite in all respects; and single. He is simple, not compounded of essence and existence, substance and accident, actuality and potentiality, or subject and attributes, as are other things. He belongs to no genus; he is inwardly and outwardly unalterable; he knows and wills all things, and first of all his own infinite self, in one indivisible eternal act. And he is absolutely self-sufficing, and infinitely happy.- Now in which one of us practical Americans here assembled does this conglomeration of attributes awaken any sense of reality? And if in no one, then why not? Surely because such attributes awaken no responsive active feelings and call for no particular conduct of our own. How does God's "aseity" come home to you? What specific thing can I do to adapt myself to his "simplicity"? Or how determine our behavior henceforward if his "felicity" is anyhow absolutely complete? In the '50's and '60's Captain Mayne Reid was the great writer of boys' books of out-of-door adventure. $\mathrm{He}$ was forever extolling the hunters and field-observers of living animals' habits, and keeping up a fire of invective against the "closet-naturalists," as he called them, the collectors and classifiers, and handlers of skeletons and skins. When I was a boy I used to think that a closet-naturalist must be the vilest type of wretch under the sun. But surely the systematic theolo- 7 gians are the closet-naturalists of the Deity, even in Captain Mayne Reid's sense. Their orthodox deduction of God's attributes is nothing but a shuffling and matching of pedantic dictionary-adjectives, aloof from morals, aloof from human needs, something that might be worked out from the mere word "God" by a logical machine of wood and brass as well as by a man of flesh and blood. The attributes $>$ which I have quoted have absolutely nothing to do with religion, for religion is a living practical affair. Other 
parts, indeed, of God's traditional description do have practical connection with life, and have owed all their historic rimportance to that fact. His omniscience, for example, and his justice. With the one he sees us in the dark, with the other he rewards and punishes what he sees. So do his ubiquity and eternity and unalterability appeal to our confidence, and his goodness banish our fears. Even attributes of less meaning to this present audience have in past times so appealed. One of the chief attributes of God, according to the orthodox theology, is his infinite love of himself, proved by asking the question, "By what but an infinite object can an infinite affection be appeased?" An immediate consequence of this primary self-love of God is the orthodox dogma that the manifestation of his own glory is God's primal purpose in creation; and that dogma has certainly made very efficient practical connection with life. It is true that we ourselves are tending to outgrow this old monarchical conception of a Deity with his "court" and pomp-"his state is kingly, thousands at his bidding speed," etc.-but there is no denying the enormous influence it has had over ecclesiastical history, nor, by repercussion, over the history of European states. And yet even these more real and significant attributes have the trail of the serpent over them as the books on theology have actually worked them out. One feels that, in the theologians' hands, they are only a set of dictionary-adjectives, mechanically deduced; logic has stepped into the place of vision, professionalism into that of life. Instead of bread we get a stone; instead of a fish, a serpent. Did such a conglomeration of abstract general terms give really the gist of our knowledge of the Deity, divinity-schools might indeed continue to flourish, but religion, vital religion, would have taken its flight from this world. What keeps religion going is something else than abstract definitions and systems of logically concatenated adjectives, and something different from faculties of theology and their professors. All these things are after-effects, secondary accretions upon a mass of 
concrete religious experiences, connecting themselves with feeling and conduct that renew themselves in sacula sceculorum in the lives of humble private men. If you ask what these experiences are, they are conversations with the unseen, voices and visions, responses to prayer, changes of heart, deliverances from fear, inflowings of help, assurances of support, whenever certain persons set their own internal attitude in certain appropriate ways. The power comes and goes and is lost, and can be found only in a certain definite direction, just as if it were a concrete material thing. These direct experiences of a wider spiritual life, with which our superficial consciousness is continuous, and with which it keeps up an intense commerce, form the primary mass of direct religious experience on which all hearsay religion rests, and which furnishes that notion of an ever-present God, out of which systematic theology thereupon proceeds to make capital in its own unreal pedantic way. What the word "God" means is just those passive and active experiences of your life. Now, my friends, it is quite immaterial to my purpose whether yourselves enjoy and venerate these experiences, or whether you stand aloof and, viewing them in others, suspect them of being illusory and vain. Like all other human experiences, they too certainly share in the general liability to illusion and mistake. They need not be infallible. But they are certainly the originals of the God-idea, and theology is the translation; and you remember that I am now using the God-idea merely as an example, not to discuss as to its truth or error, but only to show how well the principle of pragmatism works. That the God of systematic theology should exist or not exist is a matter of small practical moment. At most it means that you may continue uttering certain abstract words and that you must stop using others. But if the God of these particular experiences be false, it is an awful thing for you, if you are one of those whose lives are stayed on such experiences. The theistic controversy, trivial enough if $\rfloor$ we take it merely academically and theologically, is of 
tremendous significance if we test it by its results for actual life.

I can best continue to recommend the principle of practicalism to you by keeping in the neighborhood of this theological idea. I reminded you a few minutes ago that the old monarchical notion of the Deity as a sort of Louis the Fourteenth of the Heavens is losing nowadays much of its ancient prestige. Religious philosophy, like all philosophy, is growing more and more idealistic. And in the philosophy of the Absolute, so called, that post-Kantian form of idealism which is carrying so many of our higher minds before it, we have the triumph of what in old times was summarily disposed of as the pantheistic heresy,-I mean the conception of God, not as the extraneous creator, but as the indwelling spirit and substance of the world. I know not where one can find a more candid, more clear, or, on the whole, more persuasive statement of this theology of Absolute Idealism than in the addresses made before this very Union three years ago by your own great Californian philosopher (whose colleague at Harvard I am proud to be), Josiah Royse. His contributions to the resulting volume, The Conception of God, form a very masterpiece of popularization. Now you will remember, many of you, that in the discussion that followed Professor Royce's first address, the debate turned largely on the ideas of unity and plurality, and on the question whether, if God be One in All and All in All, "One with the unity of a single instant," as Royce calls it, "forming in His wholeness one luminously transparent moment," any room is left for real morality or freedom. Professor Howison, in particular, was earnest in urging that morality and freedom are relations between a manifold of selves, and that under the régime of Royce's monistic Absolute Thought "no true manifold of selves is or can be provided for." I will not go into any of the details of that particular discussion, but just ask you to consider for a moment whether, in general, any discussion about monism or pluralism, any argument over the unity of the universe, 
would not necessarily be brought into a shape where it tends to straighten itself out, by bringing our principle of practical results to bear.

The question whether the world is at bottom One or Many is a typical metaphysical question. Long has it raged! In its crudest form it is an exquisite example of the loggerheads of metaphysics. "I say it is one great fact," Parmenides and Spinoza exclaim. "I say it is many little facts," reply the atomists and associationists. "I say it is both one and many, many in one," say the Hegelians; and in the ordinary popular discussions we rarely get beyond this barren reiteration by the disputants of their pet adjectives of number. But is it not first of all clear that when we take such an adjective as "One" absolutely and abstractly, its meaning is so vague and empty that it makes no difference whether we affirm or deny it? Certainly this universe is not the mere number One; and yet you can number it "one," if you like, in talking about it as contrasted with other possible worlds numbered "two" and "three" for the occasion. What exact thing do you practically mean by "One," when you call the universe One, is the first question you must ask. In what ways does the oneness come home to your own personal life? By what difference does it express itself in your experience? How can you act differently towards a universe which is one? Inquired into in this way, the unity might grow clear and be affirmed in some ways and denied in others, and so cleared up, even though a certain vague and worshipful portentousness might disappear from the notion of it in the process.

For instance, one practical result that follows when we have one thing to handle, is that we can pass from one part of it to another without letting go of the thing. In this sense oneness must be partly denied and partly affirmed of our universe. Physically we can pass continuously in various manners from one part of it to another part. But logically and psychically the passage seems less easy, for 
there is no obvious transition from one mind to another, or from minds to physical things. You have to step off and get on again; so that in these ways the world is not one, as measured by that practical test.

Another practical meaning of oneness is susceptibility of collection. A collection is one, though the things that compose it be many. Now, can we practically "collect" the universe? Physically, of course we cannot. And mentally we cannot, if we take it concretely in its details. But if we take it summarily and abstractly, then we collect it mentally whenever we refer to it, even as I do now when I fling the term "universe" at it, and so seem to leave a mental ring around it. It is plain, however, that such abstract noetic unity (as one might call it) is practically an extremely insignificant thing.

Again, oneness may mean generic sameness, so that you can treat all parts of the collection by one rule and get the same results. It is evident that in this sense the oneness of our world is incomplete, for in spite of much generic sameness in its elements and items, they still remain of many irreducible kinds. You can't pass by mere logic all over the field of it.

C Its elements have, however, an affinity or commensurability with each other, are not wholly irrelevant, but can be compared, and fit together after certain fashions. This again might practically mean that they were one in origin, and that, tracing them backwards, we should find them arising in a single primal causal fact. Such unity of origin would have definite practical consequences, would have them for our scientific life at least.

I can give only these hasty superficial indications of what I mean when I say that it tends to clear up the quarrel between monism and pluralism to subject the notion of unity to such practical tests. On the other hand, it does but perpetuate strife and misunderstanding to continue talking of it in an absolute and mystical way. I have little doubt myself that this old quarrel might be 
completely smoothed out to the satisfaction of all claimants, if only the maxim of Peirce were methodically followed here. The current monism on the whole still keeps talking in too abstract a way. It says the world must be either pure disconnectedness, no universe at all, or absolute unity. It insists that there is no stopping-place half way. Any connection whatever, says this monism, is only possible if there be still more connection, until at last we are driven to admit the absolutely total connection required. But this absolutely total connection either means nothing, is the mere word "one" spelt long; or else it means the sum of all the partial connections that can possibly be conceived. I believe that when we thus attack the question, and set ourselves to search for these possible connections, and conceive each in a definite practical way, the dispute is already in a fair way to be settled beyond the chance of misunderstanding, by a compromise in which the Many and the One both get their lawful rights.

But I am in danger of becoming technical; so I must stop right here, and let you go.

I am happy to say that it is the English-speaking philosophers who first introduced the custom of interpreting the meaning of conceptions by asking what difference they make for life. Mr. Peirce has only expressed in the form of an explicit maxim what their sense for reality led them all instinctively to do. The great English way of investigating a conception is to ask yourself right off, "What is it known as? In what facts does it result? What is its cash-value, in terms of particular experience? and what special difference would come into the world according as it were true or false?" Thus does Locke treat the conception of personal identity. What you mean by it is just your chain of memories, says he. That is the only concretely verifiable part of its significance. All further ideas about it, such as the oneness or manyness of the spiritual substance on which it is based, are therefore 
void of intelligible meaning; and propositions touching such ideas may be indifferently affirmed or denied. So Berkeley with his "matter." The cash-value of matter is our physical sensations. That is what it is known as, all that we concretely verify of its conception. That therefore is the whole meaning of the word "matter"-any other pretended meaning is mere wind of words. Hume does the same thing with causation. It is known as habitual antecedence, and tendency on our part to look for something definite to come. Apart from this practical meaning it has no significance whatever, and books about it may be committed to the flames, says Hume. Stewart and Brown, James Mill, John Mill, and Bain, have followed more or less consistently the same method; and Shadworth Hodgson has used it almost as explicitly as Mr. Peirce. These writers have many of them no doubt been too sweeping in their negations; Hume, in particular, and James Mill, and Bain. But when all is said and done, it was they, not Kant, who introduced "the critical method" into philosophy, the one method fitted to make philosophy a study worthy of serious men. For what seriousness can possibly remain in debating philosophic propositions that will never make an appreciable difference to us in action? And what matters it, when all propositions are practically meaningless, which of them be called true or false?

C The shortcomings and the negations and baldnesses of the English philosophers in question come, not from their eye to merely practical results, but solely from their failure to track the practical results completely enough to see how far they extend. Hume can be corrected and built out, and his beliefs enriched, by using Humian principles exclusively, and without making any use of the circuitous and ponderous artificialities of Kant. It is indeed a somewhat pathetic matter, as it seems to me, that this is not the course which the actual history of philosophy has followed. Hume had no English successors of adequate ability to complete him and correct his negations; so it 
happened, as a matter of fact, that the building out of critical philosophy has mainly been left to thinkers who were under the influence of Kant. Even in England and this country it is with Kantian catch-words and categories that the fuller view of life is pursued, and in our universities it is the courses in transcendentalism that kindle the enthusiasm of the more ardent students, whilst the courses in English philosophy are committed to a secondary place. I cannot think that this is exactly as it should be. And I say this not out of national jingoism, for jingoism has no place in philosophy; or out of excitement over the great AngloAmerican alliance against the world, of which we nowadays hear so much-though heaven knows that to that alliance I wish a God-speed. I say it because I sincerely believe that the English spirit in philosophy is intellectually, as well as practically and morally, on the saner, sounder, and truer path. Kant's mind is the rarest and most intricate of all possible antique bric-a-brac museums, and connoisseurs and dilettanti will always wish to visit it and see the wondrous and racy contents. The temper of the dear old man about his work is perfectly delectable. And yet he is really-although I shrink with some terror from saying such a thing before some of you here presentat bottom a mere curio, a "specimen." I mean by this a perfectly definite thing: I believe that Kant bequeathes to us not one single conception which is both indispensable to philosophy and which philosophy either did not possess before him, or was not destined inevitably to acquire after him through the growth of men's reflection upon the hypothesis by which science interprets nature. The true $\rfloor$ line of philosophic progress lies, in short, it seems to me, not so much through Kant as round him to the point where now we stand. Philosophy can perfectly well outflank him, and build herself up into adequate fulness by prolonging more directly the older English lines.

May I hope, as I now conclude, and release your attention from the strain to which you have so kindly put it on 
my behalf, that on this wonderful Pacific Coast, of which our race is taking possession, the principle of practicalism, in which I have tried so hard to interest you, and with it the whole English tradition in philosophy, will come to its rights, and in your hands help the rest of us in our struggle towards the light. 


\section{PROBLEMS OF HEREDITY.*}

By W. J. V. Osterhout.

Like produces like. In this, the primary law of heredity, apparently so simple and natural, are involved problems the most profound and difficult with which science has to deal. The brilliant discoveries of the last two decades have thrown a flood of light on these problems and revealed to us how much more complicated they are than we had supposed. To-day their solution seems farther away than it did half a century ago. Nevertheless, there are here such fruitful and fascinating opportunities for research that these problems attract increased attention with every passing year and to-day are attacked with far greater vigor than ever before.

The central problem of heredity resolves itself naturally into two: first, what causes the offspring to resemble the parent? second, what causes it to differ from it? Why are some characters transmitted and others not? What characters are capable of transmission?

Certain characters are invariably transmitted. These are the race characters, i.e., characters common to an entire race or some other large group of individuals. Such characters have orginated in the remote past, persisted through a long series of generations and become indelibly fixed. The older a character is, the more certain it is of transmission and the larger the number of individuals which share it.

* Read before the Botanical Seminary, September 14, 1898. 
After eliminating the race characters there remain the individual characters, which may be of two kinds, innate and acquired. An innate character is one which is already in the fertilized egg and can commonly be traced to the parent or some more remote ancestor. Innate characters are transmissible. They include anatomical characters such as height, color; physiological characters, such as longevity, left-handedness; psychological characters, such as mental aptitudes and traits of character; teratological characters, such as supernumerary fingers and toes; and finally pathological characters, such as tuberculosis, syphilis, and many nervous disorders.

In contrast to all these characters which are already present before the egg divides, are others which are acquired in the subsequent history of the individual. Such are diseases, mutilations, development of special muscles or other organs by exercise, skill due to practice and all changes due to food, climate, or other external causes. All these are included under the head of acquired characters. Can such characters be transmitted? The question involved is of fundamental importance. A giraffe in its efforts to browse on overhanging foliage may lengthen its neck appreciably during its life-time. Will its offspring inherit this acquired character and have longer necks than they would have possessed otherwise? If so, we can easily see how the long neck of the present race of giraffes came about. It was in this way that Lamarck and Darwin explained the matter.

If we deny this possibility, we must accept the other alternative and suppose that the organ in question was variable in length and that those individuals with longer necks were able to get more food than the others and so survive them in the struggle for existence. The operation of natural selection would thus tend to produce individuals with necks longer in each successive generation until the present race of giraffes would result. This is the position held by Weismann and his school. He denies absolutely 
that a parent can transmit an acquired character to the offspring.

The principle is of broad application and of great importance in social as well as biological problems. Can an accomplished pianist transmit any portion of the acquired dexterity of his fingers to his children? Can the scholar who spends his life in intellectual pursuits hope to see his son surpass him in mental power? Can a man of criminal instincts who by severe effort succeeds in living an honest life hope to see the trail of the serpent less visible in his children?

Over these and kindred questions the battle still rages hotly without any prospect of an immediate issue. It is doubtful whether it can ever be definitely decided, for the reason that acquired characters, even if transmitted, would not be readily recognizable as such in the offspring, since it would be difficult, if not impossible, to distinguish them from variations due to other causes. If, for instance, a cat with an amputated tail should transmit to her kittens a tendency to have short tails, it is probable that no one could detect it, since the shortening would be so slight as to fall within the ordinary limits of variability. If the mutilation were continued through a sufficient number of generations, the effect should become unmistakably manifest, and if it did not, the case could be considered proved in the negative. But how many generations would be required? It may be that thousands would be necessary. When we consider how slowly the course of evolution moves this seems not improbable. We are not justified in concluding, as so many seem to, that because in a few generations no marked effect is produced, the inheritance of acquired characters is disproved. Furthermore, to render these experiments conclusive, control experiments would have to be instituted on so large a scale that the undertaking could not be continued more than a few generations at most. To disprove the inheritance of acquired characters by experiment is practically impossible and, on the other hand, to bring 
affirmative proof is, in most cases, exceedingly difficult. Such being the case, we must content ourselves for the present with a suspension of judgment.

Another side of the problem awaits our attention. We know that certain characters are transmissible, but when we observe closely we shall find that they are never transmitted unchanged. The change may be slight, almost unnoticeable, but it is never lacking. Variation is the one rule to which there are no exceptions. The origin of variations is very obscure. The utmost we can do at present is to formulate certain general laws regarding their occurrence and in some cases indicate their probable causes. They conform to rigid mathematical laws which are expressible in curves whose form varies with the individual race or species, but shows a general agreement of the most striking nature. In a body of 10,000 troops, drawn from the same country, it suffices to know that the average height is five feet, four inches, to be able to tell with tolerable precision how many men in the army are five feet, one inch high, etc. More than half the men in the army will be about five feet, four inches in height, and there will be just as many above this height as there are below it. The number of men of any given height depends on the relation of that height to the average. The nearer it approximates to the average the greater the number of men possessing it. The curve expressing these relations is identical with the binomial curve of Newton-the curve which is used to express the law of the calculation of chances. Although in some cases the curves of variation diverge considerably from this, they all conform to it in a general way.

Where organs of the same kind are numerous, they are more apt to vary in number and form than when few in number. It has also been observed that a character which is variable in one species is also variable in related species. Other general laws of variation have been formulated by various observers but are not yet settled beyond controversy. 
The sources of variation are so numerous and complicated that our knowledge of them is as yet neither definite nor satisfactory. They may be internal or external. Internal causes are more difficult to analyse and investigate, yet many variations may be referred with certainty to them. The characters of the two parents are never precisely alike, and, as they mingle and blend in the offspring, they modify each other to a greater or less degree, and so cause variation. The more dissimilar the parental characters are, the easier it is to trace their reciprocal influence. This is strikingly the case when a variety is crossed with a different variety or one species with another. It will then be seen that in some cases the parental characters blend as in the orangeflowered Canna-hybrid resulting from crossing a red-flowered Canna with a yellow-flowered one: while in other cases, they mix, producing in the hybrid just mentioned, flowers whose petals are gayly mottled with red and yellow spots side by side. Cases are not uncommon where both mixing and blending of parental characters may be seen together in the same petal or leaf.

Occasionally, the parental characters seem neither to mix nor blend, but produce something so strikingly new as to be apparently inexplicable, as, for example, when two white-flowered species of Datura are crossed and a blueflowered hybrid results. When a new character of this sort appears in either ordinary or hybrid ofispring we are naturally led to examine its previous history and to search back along the line of its ancestry to see whether the character has not occurred somewhere in its pedigree. When this is found to be the case the simplest explanation is that the character has descended from the ancestor in which it last appeared, having been transmitted in a latent condition through several generations and called again into activity when suitable conditions occured. In this case the offspring in which the character occurs is said to revert to the remoter ancestor. A child, for instance, may revert to its grand-father, resembling him far more than its own father 
or mother; a rose may produce green leaves instead of petals, in which case it is said to revert to a primitive ancestor which existed before colored petals had begun to be evolved from ordinary green leaves.

As the result of this reciprocal influence of the characters of parents and remoter ancestors the greatest variety of characters is produced. This is especially the case when different varieties or species are crossed, a fact of which the skillful gardener takes advantage to produce new races and varieties. The amount of time and patience necessary for this work are enormous but its results fully justify the outlay. The climate of California is peculiarly suited to such operations, as is evidenced by the fact that one of the largest establishments in the world devoted to creating new varieties of fruits and flowers flourishes at Santa Rosa. Here one may see endless new varieties and races in the making, acres of curious hybrids, including a cross between the strawberry and the raspberry, and many other anomalies.

While internal causes are wonderfully potent in producing variation, external causes are not less so. Changes of food and climate or other external conditions are prolific sources of variation and of these the skillful gardener avails himself just as he does of crossing. He obtains bush-peas from ordinary kinds by planting them further apart and giving them more light; he induces variations by an abundant supply of nourishment; he obtains late-flowering varieties by importing seed from northern latitudes or, if necessary, by sending seed to such points to be grown until the late-flowering habit has been acquired. Indeed, he is constantly bringing seed from distant lands in order to profit by the variations which the change of climate is sure to produce. The climate of California seems to be especially productive of variation in introduced as well as native plants. Of the latter we have a striking example in the common California poppy. Monstrosities and reversions seem to be especially abundant among plants in California. 
The great majority of variations are referable to none of the sources already mentioned. These our ignorance compels us to designate as spontaneous variations. When a single branch of a beech-tree suddenly develops deeply cut leaves while the other branches of the same tree bear leaves of normal shape, we are obliged, because we do not know its specific cause, to designate it as a spontaneous variation. As the study of variation progresses and the influence of the environment is better understood, the number of variations classed as spontaneous will, of course, diminish. Suffice it to say that at present the majority of cases of variation come under this head, which includes the most striking abrupt variations known to us.

Inextricably bound up with the subject of heredity is that of regeneration; every problem of the former finds its counterpart in the latter. The power of regeneration varies in a progressive scale. Beginning with organisms which regenerate only a few parts and these of lesser importance, such as skin, nails, and hair, it extends to those which replace lost limbs, others which regenerate a missing head or tail as well, and finally to organisms which, if chopped into small bits, produce from every piece a perfect individual. In general, the power of regeneration increases as we descend in the scale of evolution. The most simply organized forms exhibit it in the highest degree.

Most worthy of note is the fact that the regenerated member is usually developed in much the same way as the original member, whose place it is to take, but sometimes the course of development turns out to be totally different. In spite of this aberrant mode of development, the regenerated member may resemble the original one in every respect. On the other hand, a regenerated member developing in the same manner as the original one may differ from it decidedly when its development is completed. What controls the course of development in these cases? What power limits regeneration within such sharply defined boundaries, denying it to one segment of a worm when the next 
segment, precisely similar in appearance, possesses it? These and similar questions are beginning to attract increased attention in proportion as their importance is more fully realized.

Such, in brief outline, are the main problems of heredity which demand solution. To formulate a theory capable of explaining all these diverse problems from a single point of view is no easy task. Nevertheless, the attempt has been frequently made and has engaged the best abilites of thoughtful students in all ages. Antiquity, beginning with Aristotle, furnishes its quota of theories, of which some show marvelous insight while others are fantastic and absurd in the highest degree. The eighteenth century saw a great revival of interest in the subject and witnessed a hotly contested battle between two opposing schools. The Preformationists (generally known as the Evolutionists) contended that in the egg the completely formed adult existed, perfect in every part, its miniature bones, muscles, glands, etc., being completely transparent and therefore invisible. As the egg develops these simply enlarge and become visible, much as the miniature leaves of a bud unfold and produce a branch. The Epigenesists, led by Caspar Friedrich Wollf, maintained that we have no right to assume that anything is in the egg that cannot actually be seen; they contended that an egg is simple and homogeneous, without any such structures as the Preformationists assumed: these develop gradually in orderly succession until finally the adult is perfected. The controversy begun in the seventeenth century is still waged with unabated vigor, though the progress of investigation has greatly altered its aspect.

The theories of Darwin, Nägeli, His, and Weismann are essentially preformational. On the other hand, epigenetic theories have not been wanting, notably those of Hertwig, Haacke, Driesch, and others, which assume that the course of development is not fixed from the beginning, but changed and modified at every step by outside influences. 
Darwin's celebrated pangenesis theory, which was foreshadowed by several previous writers, was put forth with great modesty as a temporary working hypothesis. It was very simple in conception. Each cell of the body gives off little bodies capable of reproducing that cell under suitable conditions, much as a yeast-cell gives off buds. These bodies, too minute to be visible, are called gemmules. The gemmules collect in the sex-cells until every cell of the body is represented by at least one gemmule; consequently when the egg begins to develop, the gemmules have merely to reproduce the cells from which they sprang and each cell of the adult will find its counterpart in the offspring. Darwin did not explain how the cells of the offspring take on the proper arrangement and in other important respects his theory is entirely inadequate. He was, however, the first to see and admit defects in his theory and join in hoping for a better one.

The theory of the celebrated botanist, Nägeli, was an important step in advance, inasmuch as it introduced a new conception destined to prove of great value. Not the entire egg, said he, is a vehicle for the transmission of hereditary qualities, but only a small portion of it, the idioplasm. The remainder of it is nutrient plasm, i.e., living substance which nourishes the idioplasm but is not directly concerned with heredity. Nägeli did not identify the idioplasm with any definite structure in the cell but later the zoölogist, Hertwig, and the botanist, Strasburger, showed that Nägeli's idioplasm was contained in the nucleus. Another botanist, de Vries, added a fruitful conception in his suggestion that the idioplasm of the nucleus is made up of numerous smaller units, each of which is the bearer of a distinct hereditary quality. As long as they remain in the nucleus they are latent, but when they migrate out of the nucleus into the cell they become active and give their characters to that cell. Hence we can see how two cells lying side by side and possessing the same idioplasm may develop, the one into a bone-cell, the other into a muscle-cell. 
Following up this clue, Weismann, with the aid of several brilliant suggestions from Roux, has devised an elaborate system of theories by means of which all the facts of heredity may be explained. It is the most complete theory ever put forth and, if all its numerous assumptions be admitted, the most logical. As such, it has attracted more attention than any other and caused endless controversy. Its most important features are the structure of the idioplasm and the struggle for existence of its elementary units. The idioplasm, which Weismann terms the germ-plasm, is composed of elementary units, the biophores, each of which bears a special character or quality which it confers upon the cell containing it. Each cell contains at least as many biophores as it has qualities. A biophore is capable of duplicating itself by division into two precisely similar biophores; these may divide again repeatedly and so multiply indefinitely. They are capable of growth and self-nutrition. All the different biophores of a cell taken together constitute a group called a determinant. There are, of course, as many different sorts of determinants as of cells. If all the determinants of any individual are collected in a group they form an id. An id, therefore, contains determinants enough to furnish all the cells of a perfect individual. According to Weismann ids are large enough to be visible with the microscope and are identical with the chromatin granules of the nucleus. Now the germ-plasm, of an egg for instance, contains a large number of ids. Only one of these becomes active; the others remain in a passive or latent condition. When the egg divides into two daughter-cells, one-half the active id goes to each of them. When the two daughter-cells divide in turn, each of the four resulting cells receives onefourth the active id. As this process continues the active id is broken up into smaller and smaller pieces and finally disintegrates into separate determinants, of which each cell receives one. The determinants now break up and the biophores which compose them migrate out of the idioplasm into the cell and there becoming active, give to the cell their 
peculiar characters. The origin of all the cells of the body each with its own special characteristics is thus accounted for. But what determines how the cells are to arrange themselves properly to form bones, muscles, etc.? This orderly arrangement of the cells is due to the arrangement of the determinants in the id; they are packed into the id in such a way that when it is broken up into successively smaller pieces the determinants are inevitably set free in the proper order. The architecture of the id thus becomes a factor of prime importance, since on the arrangement of its parts depends the arrangement of cells in the individual. Any slight disturbance of this arrangment might result in a monstrosity.

Having now explained how the offspring may resemble the parent, cell for cell, it remains to see how it may vary from it. In the first place much depends on the selection of the active id. In the germ-plasm of the egg are hundreds of ids, accumulations of the past, each exactly like the active id of some previous ancestor. Clearly it depends on which id is called upon to become active whether the child is to resemble his parent, his grand-parent, or some previous ancestor.

The most active source of variation is, however, changes which are continually taking place in the germ-plasm itself, due to the struggle for existence which the biophores earry on among themselves. This happy suggestion, adopted from Roux, carries the principle of natural selection and the survival of the fittest down to the smallest hypothetical units of living substance. Just as man struggles with man, plant with plant, tissue with tissue, cell with cell, so biophore struggles with biophore, and the fittest survive. And just as the struggle for existence results in continual change in human society or in plant communities, so the struggle between biophores results in constant change in the community of biophores, that is, in the germ-plasm. 
We have thus a simple and beautiful explanation of spontaneous variation but none as yet of variations due to outside influences such as changes of food, climate, etc. In truth, this class of variations cannot be satisfactorily explained by Weismann's theory, and his efforts to do so are foredoomed to failure. The course of development is predetermined in every detail by the structure of the active id and cannot be modified by external influences. The organism is built, like the Temple, of pieces hewn and shaped beforehand according to the plan of the builder, which makes no allowance for change or modification during the erection of the edifice. Weismann's attempts to strengthen this weak point in his theory have not thus far been very successful. Variations due to the reciprocal influence of the characters of the two parents on each other are explained by supposing that the respective portions of the germ-plasm bearing these characters fuse in the egg and so cause them to mix or blend.

The matter of regeneration remains to be considered. Weismann considers this a character brought about by natural selection, not a primitive character. It is due to certain latent ids or parts of ids which are especially allotted to certain parts of the body for regenerative purposes.

The remainder of the latent ids are conserved in certain special cells in order to supply germ-plasm for the future offspring. These cells give rise to the sex-cells which in turn give rise to new individuals. Hence there is an unbroken continuity of germ-plasm from generation to generation. Individuals spring from it and presently die but the germ-plasm lives on forever, producing new individuals in endless succession, as a tree sheds its dying leaves in autumn but reclothes itself in fresh verdure with each returning spring.

Since each individual uses up in its development one of the ids of the germ-plasm, the stock of ids would not hold out were not the ids capable of duplicating themselves as 
often as necessary by division into two. The supply of ids is maintained solely in this way: it receives no accessions from the individual in which it is contained: the individual merely conserves the germ-plasm and passes it on to the next generation without modifying it or influencing it in any way. Hence outside influences, such as changes of climate or food, which modify the individual, cannot affect the germ-plasm nor can it be changed in any way by the exertions of the individual. Hence the transmission of acquired characters is impossible. This part of the theory, which Weismann developed some years ago, and in which he asserts the unchanging character of the germplasm, contradicts his latest assumption that the germplasm is constantly changing as the result of the struggle for existence among the biophores. In making the latter assumption Weismann does not intend to admit the possibility of transmitting acquired characters, but he nevertheless unwittingly opens the door to such an admission. The struggle of the biophores in the germ-plasm is a struggle for food: that food comes from the individual: any influence which affects the individual affects the food which it supplies to the germ-plasm and the kind of food furnished to the germ-plasm may determine which particular set of biophores shall triumph in the struggle for existence. Thus is opened a way in which an acquired character may be transmitted to the germ-plasm and through it to succeeding generations.

The elaborate care and logical completeness with which it is wrought out render Weismann's theory fascinating to a degree, but its completeness is due to a system of complicated hypotheses which nowhere rest upon a firm basis of fact. The quasi-metaphysical nature of the theory eludes the ordinary criteria of observation and experiment.

If we consider heredity from the standpoint of epigenesis, we are able to dispense with this cumbrous and complicated system of assumptions and refer all the facts to a single principle, thoroughly tested by every day observation 
and experiment and at every point in touch with fact. The Epigenesists have wisely refrained from trying to formulate a theory as complete and comprehensive as that of Weismann. Indeed in the present state of our knowledge, it is highly inadvisable to attempt it. For them, development is merely a manifestation of the fundamental property of protoplasm, irritability. By irritability we mean the property which protoplasm has of responding in different ways to different external stimuli. Without this property life is inconceivable, since life depends on a delicate adjustment of living substance to its surroundings.

The egg-cell, like every other cell, has its own peculiar way of reacting to each external stimulus. It is not restricted in its development to a single narrow groove, but may develop in different ways according to the conditions which surround it. It has been shown beyond possibility of doubt that the external environment may profoundly modify the form, size, and internal structure of cells and multicellular organizations: that it may determine whether one or several embryos shall arise from an egg, that it may excite or inhibit cell-division and may control its rate: that it may call forth structures which are new in the history of the organism: that it may determine whether a mutilated organism shall regenerate a head or a tail at a given point; that it may, in some cases at least, determine sex. In view of these facts we must acknowledge that environment profoundly modifies and alters the course of development at every step and is a factor of far more importance than Weismann would admit. It writes its name large on the developing organism and its record remains indelible. This would be impossible did not the egg-cell and every other cell receive from it constantly stimuli which determine the course of their development. Not only so but each cell constantly receives stimuli from all the other cells: its position with reference to them determines whether it shall develop into a bone-cell or a muscle-cell. Its destiny is fixed by its cell-environment. 
There is, moreover, no such profound difference between the egg-cell and other cells as Weismann postulates. Not only the egg-cell but every cell of the body may, and in many cases certainly does, contain germ-plasm sufficient to reproduce the individual under proper conditions. Regeneration and vegetative reproduction is thus explained in a simple and natural way. When the whole course of development is conceived of as a series of reactions to external stimuli and when we consider what an astonishing variety of such stimuli act upon every cell, the reason becomes plain why variation is the invariable law of heredity and development. When we consider how slight a cause may alter development, the introduction of a minute quantity of substance from an insect's sting causing a plant to produce a gall whose structure is totally different from anything prescribed by the hereditary history of the plant, we may well wonder that species and races are as constant as they are. Only the general uniformity of conditions can account for it.

Of the two factors of heredity, inherited tendencies and environment, the Preformationist lays weight on the former, the Epigenesist on the latter. The one emphasizes internal, the other external forces. Evidently there is truth in both sides. The epigenetic theory, however, appeals to the investigator as a more direct and natural explanation of the facts, affording a sound basis for experiment, elastic enough to cover all cases, and in touch everywhere with observed fact.

Moreover, the progress of investigation points with growing emphasis to the environment as a determining factor in development. It is true that the manner in which the egg reacts depends on its inherited structure. It is not necessary, however, to assume with Weismann that this structure depends on a fixed and wonderfully complicated arrangement of granules. Such a conception is irreconcilable with the facts of metabolism. It is far more probable that its chemical composition is the significant 
thing. Indeed the whole question is rapidly approaching a physico-chemical basis. It is clearly seen that the study of heredity will in future be an investigation of the physical and chemical reactions of the cell with its environment and that here the whole explanation lies hidden.

The great problems of heredity are, therefore, cellproblems and these in turn are problems of physics and chemistry. For their solution the physicist and chemist must prepare the way: the biologist may then hope to approach by experimental methods a step nearer to the ultimate causes of inheritance and development.

$$
\text { * * * * * }
$$

In view of the wide-spread popular interest in the subject and its fundamental importance in many fields a guide to the most important literature is greatly needed. The following list was prepared for the Botanical Seminary which devoted the past year to the study of heredity and will continue the work during the present one. This list includes only a few of the most important accessible publications bearing on the topics mentioned.

A card catalogue of the most important literature of heredity has been prepared for the use of the Seminary and is at the service of all who may wish to consult it.

General:

Wilson, E. B.: The Cell, 296-330.

Haacke, W.: Grundriss der Entwickelungsmechanik, 172-185.

Thompson, J. A.: The History and Theory of Heredity. Proceedings of the Royal Society of Edinburgh, 1889.

Brooks, W. K.: Heredity, 16-80.

Hertwig, O.: Aeltere und neuere Entwickelungs-theorien. Berlin, 1892.

Are Acquired Characters Inherited?

Romanes, G. J.: Darwin and after Darwin, II. 39-158.

Weismann, A.: The Germ-plasm, 352-391.

Delage, Y.: L' Hérédité, 186-216, 235-241.

Darwin, Ch.: Animals and Plants under Domestication, II. 9-41, $81-108$, and 302-428.

Osborn, H. F.: American Naturalist, 1892, 537-567. 
Non-Resemblance of Parent and Offspring.

Delage, Y.: L'Hérédité, 222-233, 242-259.

Darwin, Ch.: Animals and Plants under Domestication, II. Chap. XIII-XIX.

Darwin, Ch.: Origin of Species, Chap. IX.

Bailey, L. H.: Plant Breeding.

Bateson, W.: Materials for the Study of Variation.

Nägeli, C.: Die Bastardbildung im Pflanzenreich. Sitzungsberichte der königlichen bayerischen Akademie der Wissenschaften in München. December 15th, 1865. Also Botanische Mittheilungen, II. 187.

Theories of Darwin and his Predecessors.

Darwin's Predecessors.

Delage, Y.: L'Hérédité, 354-358.

Whitman, C. O.: Wood's Holl Biological Lectures. 1894.

Brooks, W. K. : Heredity, 20-27.

Osborn, H. F.: From the Greeks to Darwin.

Wolff, Caspar Friedrich: Theoria generationis; Uebersetzt und herausgegeben von Dr. Paul Samassa. Leipzig, 1896.

Darwin's Theory.

Darwin, Ch.: Animals and Plants under Domestication, II. 428-481.

Brooks, W. K.: Heredity, especially Chap. II and III.

Delage, Y.: L'Hérédité, 534-550, et seq.

The Theory of W. His.

His, W.: Unsere Körperform und das physiologische Problem ihrer Entstehung. Leipzig, 1874.

Delage, Y.: L'Hérédité, 468.

Wilson, E. B.: The Cell, 297.

The Theory of C. Naegeli.

Nägeli, C.: Mechanisch-physiologische Theorie der Abstammungslehre.

Nägeli's Theory of Organic Evolution: Summary. Open Court Publishing Co.

Delage, Y.: L'Hérédité, 592-643.

Wilson, E. B.: The Cell, 300.

Wiesner, J.: Die Elementarstructur und das Wachsthum der lebenden Substanz. 
The Theory of H. De Vries.

de Vries, H.: Intracellulare Pangenesis.

Delage, Y.: L'Hérédité, 645.

Wilson, E. B.: The Cell, 303.

Haacke, W.: Gestaltung und Vererbung.

Weismann, A.: The Germ-plasm, 12-20 et passim.

The Theory of A. Weismann.

Weismann, A.: The Germ-plasm.

Hertwig, O.: The Biological Problem of To-day.

Wilson, E. B.: The Cell, 303.

Delage, Y.: L'Hérédité, 512, 667, 724.

Romanes, G. J.: An Examination of Weismannism.

Roux, W.: Gesammelte Abhandlungen, Vol. I. 135-422; Vol. II. 125-143, 871-881.

The Theory of W. HaAcke.

Haacke, W.: Gestaltung und Vererbung.

Grundriss der Entwicklungsmechanik.

The Theory of O. Hertwig.

Hertwig, O.: The Biological Problem of To-day.

Delage, Y.: L'Hérédité, 663.

Wilson, E. B.: The Cell, 312-317. 


\title{
UNITY IN VARIABILITY.
}

\author{
By Hugo de Vries.*
}

\author{
Alle Gestalten sind ähnlich \\ Doch keine gleichet der andren \\ Und so deutet das Chor \\ Auf ein geheimes Gesetz.
}

The idea which underlies these words of Goethe had been expressed long before by Cats in these lines:
Als van twee gepaarde Schelpen
G'eene breekt of wel verliest,
Niemand zal a kunnen helpen,
Hoe ge zoekt of hoe ge kiest; $\dagger$

and afterwards by Darwin in his well known assertion that no two individuals of the same kind are alike.

We may therefore consider it as a generally acknowledged and fundamental principle of heredity, that individual differences are everywhere present, affecting every character of the organism.

But the general acknowledgment of this fact does not disclose to us the law by which it is governed. The "geheimes Gesetz," the existence of which was already

* An inaugural address delivered by Hugo de Vries, Professor of Botany at the University of Amsterdam, in his capacity of Rector Magnificus on the last dies natalis of that University, January 8,1898. It appeared originally in the "Album der Natuur," No. 3, 1898, publisher H. V. Tjeenk Willink, Haarlem, Holland. Translated from the Dutch by H. T. A. Hus, and revised by the author. This translation was made for the use of the Botanical Seminary, and was read September 28, 1898.

fIf of a pair of shells, one is lost or broken, it will be impossible to find one which will exactly replace it. 
suspected by Goethe, remained a suspicion, or rather a scientific conviction, founded on the fundamental principle of the general validity of the laws of nature.

It was reserved for the Belgian anthropologist, Quetelet, to discover this law, for he felt that only a scientific treatment could lead to a solution of this problem. And a scientific treatment requires first of all that the study of individual differences should not be made in a general way, but should be restricted to a single character in its different phases of development in different individuals. For this is the scientific "divide et impera," the motto to which Natural Science owes its greatest triumphs.

Quetelet chose a single quality, which can be determined conveniently for a large number of persons, and which is actually measured at the time of registration for military service. He chose the height of the body at the age of conscription.

The law which he discovered as a result of his investigations was as surprising as simple. Imagine several thousand recruits, from a certain part of the country, and without further selection ranged in line according to height. Imagine a curve drawn over their heads. This curve will then represent the variability of the height of the recruits.

It now becomes apparent that most of them, far more than half the number, are of about the same height. The line over the heads of these individuals has but little inclination, is in fact nearly horizontal. But towards both ends of the curve the differences increase; towards the one end the line rises quicker and quicker, towards the other end it descends in the same manner. Exceedingly tall and exceedingly short men are very rare; more than half do not deviate essentially from the average height.

This would be evident to anyone to whom such a curve were shown with this intention. But to Quetelet it meant more than this. He recognised in this curve a formula well known in science, a formula already carefully studied 
by Newton, and the qualities of which are thoroughly known. It is the curve, the direction of which is fixed by the binomial theorem of Newton, the curve which forms the basis of the calculations of probability, the curve which, because of its application to life insurance and pension laws, is of such great importance in practical life.

In short the discovery is this: the variation of the height of the human body follows the laws of the calculations of chance.

And if such an exceedingly simple law is true for the height of the human body, it is impossible that its validity is limited to this single ease. If our convictions in regard to the laws of nature are right, reasoned Quetelet, then the same law must govern the whole field of variability. It must hold true for all qualities of man, physical as well as intellectual and moral qualities, it must hold true for the plant kingdom as well as for the animal kingdom; in short, it must include the whole living world.

It is now nearly thirty years ago that the famous work of the great Belgian scientist, Anthropometrie, made its appearance. It opened a new field of investigation. With the eyes of a seer he viewed the vast territory which promised to bear such rich fruit to science. "Know thyself," became for him: know all thy qualities, know their measure and number, and know them in comparison with those of others.

To reach this goal is not the work of one mind, however privileged it may be. The labor, study, and lifelong devotion of many are necessary to gather the materials by the aid of which the solution of the great problem may be found. Here we may notice two distinct lines of investigation.

The validity of Quetelet's law for the whole animal and plant kingdom, prophesied by this great thinker, requires for its proof numerous investigations. For every character many hundreds of individuals of the same kind must be measured and compared. Wallace, in his work on 
Darwinism, was one of the first to undertake this task in Zoölogy. The peculiar drawings, entirely composed of black dots, which illustrate this part of his work, show us at a glance the great difficulties with which he had to contend. But the results clearly bear out Quetelet's hypothesis. He was followed by Weldon, with ample and very careful measurements of shrimps, Lloyd Morgan with his studies on bats, Bateson with studies on earwigs and other insects, and numerous others. In every instance the general law was confirmed.

Among botanists the first determinations were made by Fritz Müller who at once made use of his investigations to confirm Darwin's theory of descent. He studied especially ears of corn. Here the seeds are arranged in double rows, the number of which is variable, and this variability follows in every respect Quetelet's law. He was followed by others, among whom Ludwig is prominent. The latter counted the number of rayflowers on the capitula of the Compositæ, the number of pedicels in the umbels of Umbelliferæ and the number of leaves of many kinds of branches of limited growth. He found that in this field also, which formerly seemed so purely morphological, all phenomena are governed by Quetelet's law.

Sugar beets yield quite a different kind of illustration. In the improvement of the races of this highly important plant, the sugar percentage is of course the most important factor. Only those beets, the roots of which are rich in sugar, are suitable for propagation. They are carefully selected and planted for seed, which in the following year produces the new generation. The methods used in the investigation of the sugar percentage, surpass in brilliant results those of most other subdivisions of applied science. In the factory of Messrs. Kuhn \& Co., near Naarden, Holland, every year in the short space of six weeks, during which the beets are available for analysis, the sugar percentage of no less than 300,000 beets is determined. This 
analysis gives a number to each beet, which indicates its richness in sugar.

So much material could probably never be accumulated for a purely scientific purpose and vies in importance with the annual measurement of recruits. It may be of as great import as these measurements, while at the same time it may serve as an instance of a quite different field of investigation, since it represents the chemical properties of plants and enables us to extend the investigation of the validity of Quetelet's law to these also.

The work of the last few years furnishes a brilliant confirmation of this law, fully verifying its prediction. A mere arrangement of a fifth or a sixth part of the numbers found in one year is sufficient to remove all doubt. If every number is represented by a line, expressing by its length in centimeters the size of the number, and if these lines are arranged in the same manner as the recruits, while their tops are joined by a curve, we will find that this curve is the same as that of Quetelet, only on a different scale. More than one-half of the beets agree quite closely with the average of the race. Towards the side of the highest sugar percentage the curve rises at first slowly, then faster and faster, till towards the end it reaches but a few highly privileged individuals. Towards the other end the curve descends, descending rapidly along the lines of the poorest beets. Thus we have a simple, regular figure, symmetrical in both halves.

It would be unnecessary to cite more instances. They all confirm the hypothesis that the variability of the species and the individual differences are subject to as fixed laws as all other phenomena of nature; that the same law governs the variability over the whole field of living nature.

With perfect confidence one can express the hypothesis in this form: In living nature nothing is more fixed than variability. "Unity in variability" is therefore the title of this paper. 
The second direction of study in this field is more directly concerned with man, and especially with those qualities which stand in closest relation to his happiness in life. The foremost worker in this field is Francis Galton. He has endeavored to show that the mental and social qualities of man are also subject to the general laws.

There are two standards by which the mental gifts of men may be judged on so large a scale, su as to be available for Galton's investigations. They are on the one hand examinations, on the other, social suecess, what is commonly called "making one's way in the world."

Both have been studied by Galton. He laid the foundation in his famous work, Hereditary Genius, which appeared at about the same time as Quetelet's Anthropometrie (1869). Here he pleads for the heredity of genius. It is true that genius is not a single quality, but is composed of at least three others: talent, ambition, and energy. They are according to Galton the essential components. Only where these three are found together does one succeed in nearly every case in surmounting all social difficulties, and succeed in reaching the highest level in intellectual endeavor and in the estimation of his fellow-men. The estimation of his fellow-men is according to Galton a measure of genius.

A vast number of instances have been collected in this book. One admires the talent with which these seemingly vague facts, apparently so little adapted to numerical treatment, have been forced to take tabular form. And when this has been done, the table shows at a single glance how the laws of heredity and variability, which govern the physical qualities of man, can also be applied to the highest social qualities. What can be more dissimilar than height and genius, and yet both obey the same laws.

Galton also made examinations a subject of study. At Cambridge (Eng.), the results of examinations are usually expressed in numbers. Galton collected these data for the examinations in mathematics for a number of years, 
calculated them, and found that they closely followed Quetelet's law. Very good and very poor numbers are as rare as very tall and very short people; more than half hardly differ from the average.

In connection with this investigation he also considered the question, what part have education and training in the ability of a man. Doubtless this part is not small, but still it is usually highly overestimated. Talent determines in general the place of the individual upon the line of Quetelet. Education and training are indispensable to anyone who intends to take the place which is his due, but they will not lead to considerable advancement on that line. No training can take the place of talent. For instance, it has long been a well-known fact that every year the most experienced mountaineers are surpassed by quite inexperienced persons.

Education and instruction ought above all to lead each student to know which of his talents is most fitted for further development, so as to enable him to form a suitable choice of his future sphere of activity. Our school system improperly tends to a uniform development of the students. The university privilege of educating each student according to his particular talent, ought to be extended to all instruction. But however enticing the subject may be I may not enter deeper into a criticism of the nature and aim of examinations. For the studies of Galton lead us to draw a quite different conclusion, which promises to exercise a preponderating influence on future investigation. The study of mental characters leads us to consider these also as congenital characters and as a result the question arises by what causes they are determined.

It is clear that natural talent depends on ancestral influences. But these characters must also be governed by general laws, laws which must again be the same for mental gifts as for physical characters, the same for men, animals, and plants.

Shall we ever succeed in discovering these laws? It is in reality an ideal which to many seems unattainable. 
But investigation has already advanced so far, that we may believe in the possibility of its attainment. We may even consider what fruit the knowledge of these laws will one day bear to society. Will man, by knowledge and regulation of these influences, ever be capable of exercising an arbitrary control on natural talent? And will this control lead to an increase of human happiness?

But we can not go too far in the way of speculation. For an answer to the question, What are the natural causes of mental gifts? may from the very nature of the case, be expected only after a prolonged investigation. That this investigation will be exceedingly difficult, long, and extensive, will be conceded by every one. We must proceed step by step, and we may consider ourselves fortunate, if we find the right road which shall one day lead us to the great goal.

It has been known for a long time that the causes which here come into play belong to two great groups, heredity and variability. The resemblances in certain characters between children and their parents depend, it is said, on heredity; the differences on variability. Both names only indicate the phenomena; about the causes they give no information.

The search for these causes is something quite different from the study of the phenomena themselves. The phenomena of heredity in man have been studied very extensively by Galton. He compared the characters of the children with those of the parents and grandparents, and even with those of their relations outside the direct line. He investigated the physical qualities as well as the mental gifts. The difficulties with which he had to contend were very great. The ordinary statistical data proved almost useless. They acquainted him with the characters of the individual as separate facts, but did not give them in relation to those of the parents. But precisely this was the important point. New comparative observations had therefore to be made for every question, and very soon the 
exceeding difficulty of gathering these in sufficient numbers became apparent. Every step increased the difficulties, and very soon they became insurmountable. And besides, where research not only aims at the knowledge of the phenomena, but also at a study of their causes, the purely statistical direction is only too often found to be of no avail. Experimental investigations must here take the place of the collection, arrangement, and calculation of observations.

But man does not lend himself to experiments of this nature. These can only be made with animals or plants. Besides, the developmental tendency of physical characters is much more easily determined than in the case of mental gifts. The goal must therefore be reached not directly but indirectly.

And when, in plants for instance, the laws governing developmental tendeucies have been discovered, we will certainly have taken an important step towards the great goal-the causes of the mental gifts of mankind. For the basis of all investigation is the conviction that the laws of nature hold true in all cases. What is true for plants in general must be true for the animal kingdom and for man; what is true for the physical characters must also be true for mental gifts.

We must be able to apply the laws which will be discovered for the variability of plants to society and its exceedingly intricate workings of cause and effect. And how much easier it is to apply an hypothesis to a new case, however intricate, than to formulate it originally.

It is a beautiful ideal. To contribute to the advancement of human happiness is the great aim of all science. What a satisfaction for the quiet investigator, working in retirement, to be able to picture to himself the way in which the fruits of his study will at some time be used for this object.

Experimental investigation of the causes which govern developmental tendencies is impossible with man. With animals it is exceedingly difficult and expensive; with plants 
it comes within the reach of the ordinary physiological experiments.

But the difficulties even here are very great. Every experiment lasts at least a generation, most of them last two or three, many a still larger number of generations. This excludes man and the higher animals from investigation, since the experiments would take too much time. For the same reason nobody would think of choosing trees for the study of heredity. Animals, and biennials and perennials that flower and produce fruit during the first or second year of their existence are the proper material for the study of heredity.

If every generation takes one year, and if an experiment requires, as is frequently the case, eight or ten generations, then the investigation will proceed slowly enough.

Some species of animals produce in one year several generations, for instance rats and mice, moths and other insects. For this reason they have been used repeatedly for experiments on heredity. But in performing the experiments, so many difficulties have been encountered, that plants must be preferred in nearly every instance.

The principal theoretical advantage of experiments with plants lies in the possibility of bringing up the number of individuals to a height, which cannot possibly be attained with animals even at great pecuniary sacrifice. One can, for instance, without any great trouble, grow yearly 600 to 800 specimens of Chrysanthemum segetum, choose at the time of flowering 10 to 12 of the best, and reject the rest. How exceedingly troublesome would an experiment with animals become, were one to make as small a selection from as large a number of individuals. For the rigidity of the selection depends in the first place on the relation between these two numbers. Indeed, the whole result, the degree of accuracy which ean be obtained depends principally on the number of plants and animals in each generation. No amount of care in the work can ever make good any neglect in this regard. 
In this direction we can go much farther with plants. I mean, in cases where the character studied can be determined already in the seedling. To determine an average number for the hereditary power of the mother plant in 300 to 400 seedlings, is a work which does not take many hours, and which, in every generation is easily performed for about 30 to 40 seed-bearing plants. One thus judges and counts yearly fully 10,000 individuals for a single experiment, and selects from among this number the 30 or 40 best ones for the next year.

The law of the calculation of chances has been called by Poisson "The law of the large numbers." It depends then chiefly on the large numbers; to avoid diverging from this precept, especially when it is a matter of exceedingly accurate experiments, is possible with plants only.

Plants offer a second great advantage in the structure of their flowers, in which in the majority of cases stamens and pistils are present together. One single individual of selected characters may be chosen for ancestor, while in the case of animals two are always necessary. The choice is therefore more rigid and safer and one does not need to consider an average between the parents in the calculations.

Finally plants may be grown under far more natural conditions than is possible for animals in similar experiments. Rats and mice, living in relatively small cages and isolated as much as possible for the purpose of a careful choice, do not lead a natural or agreeable life during the experiments. The same is true for the moths grown by Merrifield, which for the sake of the coupling of the best, had to be measured, one at a time, under the microscope.

As soon as it becomes necessary to perform experiments to determine the influence of food, beneficial or otherwise, upon the developmental tendencies of the descendants, the first requirement is, of course, to make all other conditions of life as favorable as possible. This is very easily performed for plants, but with great difficulty for animals. 
If we consider these arguments together, we can safely prophesy, that scientific experiments on heredity and variability form a task especially reserved for the botanist. There is a large choice of species, many individuals find room in a limited space, judgment and selection of the best is practicable for a large number, isolation during the flowering period, if necessary, aided by artificial fertilization, forms no objection, and nutrition may be regulated closely in accordance with the needs of the experiment.

About half a century ago, Schleiden, uniting the results of the work of numerous investigators during the first period of microscopic investigation, formulated the hypothesis, that all plants are built up of cells. Schwann applied this hypothesis to the animal kingdom and to man. It is now acknowledged by everyone, that the cell-doctrine forms the basis of the whole of our knowledge of the more minute structure of organs and tissues, the components in which the source proper of life is situated. We, therefore, hope (and we feel satisfied that it will be so) that when we have discovered the nature and causes of individual differences for plants, we will be able to apply them to man in the same manner; to his physical characters as well as to his mental ones, since the latter are our final goal.

After enlarging upon the ideal which must guide the investigator we come to the practical part of the investigation.

This has up to now concerned itself chiefly with two causes, which govern variability. The one is heredity in a narrower sense, the other nutrition. Let us follow these up separately.

We may speak of heredity in a wider, and in a narrower sense. The individual inherits first of all, the general character of the species to which it belongs. This is heredity in the wider sense of the word. But besides this, the individual bears, as a rule, a greater resemblance to its parents than to the average type of the species. It inherits, therefore, also, or at least in part, the individual characters of the parents. This we call heredity in the narrower sense. 
Heredity in the wider sense is the basis of the common descent of species. Exceptions, or rather deviations from the rule are not general, but sudden, each time originating a rarity. A union (accumulation) of a certain number of varietal characters forms a new species. Heredity in the narrower sense stands in no relation to the origin of speeies; it remains within the limits of the species; it gives existence to races, but not to varieties. If we take account of the degree of variability peculiar to each character of a species, ${ }^{*}$ the "Formkreis," as Hanstein so happily called it, appears larger than is suitable for an ordinary diagnosis. It is possible that because of this the limits of related species become more difficult to fix, but it does not make them less firm and immovable.

It is not my intention to discuss in this place heredity in the wider sense of the word. According to Ranke and Virchow, it seems that for man heredity has become perfectly fixed since the neolithic period. Therefore, nearly all differences which we notice between our fellow-men belong to the field of heredity and variability in the narrow sense. Let us, therefore, return to this field.

Every character is variable within certain limits. The blue of Centaurea cyanus or the red tint of the blossom of Erica may seem always the same to us, yet a careful comparison shows the existence of innumerable gradations between light and dark blue, between pink and the darkest red; gradations which ever follow the law of Quetelet.

But if we select for sowing, a seed of the darkest and of the palest cornflowers separately, what will be the color of the new generations? Experience teaches us that the two groups of plants will be dissimilar, the deep blue parents having deep blue descendants, the light colored ones a light colored progeny. In each group the color is variable, unequally so in the different plants. In each group the

\footnotetext{
* Continuous variability, in opposition to discontinuous or sudden variability, which comprises the deviations from the rules of heredity in the wider sense of the word.
} 
deviations follow the general law. But the average is different for the two.

One would be led to expect, that this average of characters of the children would agree exactly with the color of the parents. But this is not the case. The average of the children deviates from the type of the species much less than did the parents. There is a return to the original type, a regression, to use a term introduced by Galton. "Les variations nouvelles rayonnent autour d'un point, placé sur la ligne qui sèpare la type de la première deviation obtenue," wrote Louis Vilmorin, the first one to study heredity and variability in cultivated plants. (Notices sur l'Amélioration des plantes, 2d Ed. 1884, p. 34.)

This regression, formerly sometimes called atavism, is considerable; it amounts to about one-half of the deviation, and according to Galton, in certain cases to two-thirds of the total.

In other words, highly developed parents have average children, which are better than the type of the species, but deviate from it less than the parents themselves. This is a rule which has been confirmed on a large scale for plants and animals by the experience of more than half a century and which also holds true for man, for his height as well as for his mental qualities. The best known instance is the grenadiers of the guard of Frederick the Great. Selected because of their height from the entire population, the results of heredity became apparent in the next generation; the children of the grenadiers furnished the greatest contingent of grenadiers; succession in the above guard became a natural nepotism. And that the same thing is true for mental gifts has been amply shown in Galton's book on hereditary genius.

We will take another step. If from the seedlings of the dark blue Centaurea we again select the darkest flowers for the gathering of the seed, and if this process is repeated for some generations, what will be the result? This method is called selection, and gives rise to a race. Because the 
average was better than the type of the species, the best ones will, after selection and with the same degree of variability, be better than those originated without selection. From each generation one can, therefore, select better plants than from the preceding. Regression does, of course, take place in each generation, but in consequence of the repeated and improved selection, the average of the race improves gradually.

Shall we be able to proceed in this manner without limit, and finally succeed in producing a race which surpasses the original species in any degree we may wish? Certainly not. On the contrary, the farthest limit is reached comparatively soon. After four or five generations of careful selection, there remains but little chance of farther improvement, at least as long as the method of selection remains the same. This fact is best known on a large scale for the sugar-beets already mentioned where an improvement is now possible only by continued improvement of the method of selection, and by applying this selection not only to the sugar percentage but to other qualities also, for instance, to the weight of the beets.

Hence, as a rule, we obtain as a result of selection, a constant race. But-and this is the great objection, the point in which a race is so far inferior to a species or variety-though the race is constant, it is not independent. Originated with selection, it is only with the continual aid of selection that it can persist. If selection ceases, the descendants of even the most noble race will return in a few generations to the type of the species.

A hard, a difficult, I should be inclined to say, a sad law. What is obtained with much trouble and care can be preserved only by as great care and trouble. And history is witness that this law is also true for mankind. Everywhere and always progress-but followed by regression as soon as the effort ceases.

There remains but a single point for discussion. Selection of the best, is the motto resulting from the contemplation 
of heredity. The other topic, which up to now has been the subject of observation, is the inquiry into the part played by the food.

This last point is also the most difficult, and because of this has been studied least of all. What influence has food on developmental tendencies? Can one, by improving the food, produce more highly gifted individuals?

That there exists a close relationship between food and variability is generally known. Darwin has accumulated a large number of facts to prove this. In nature, where food is less plentiful, the inequality is generally less than in culture. Considerable deviations in wild plants are usually met with on either very poor or very rich soil. Dwarf specimens of all species are frequently found on the sand dunes of our shores. On the other hand, the term "luxuriant" indicates how general is the opinion that on rich soil specimens of various plants are found, which deviate favorably from the type.

Artificial nutrition, rich manuring, increases variability. Manure heavily to improve your races, but be economical with manure if you want them to remain constant, is a rule known to all seed-growers.

But these are merely general considerations. It only becomes a science, when one commences to investigate the variability of a single quality in its relation to nutrition, especially in regard to decided improvements in nutrition. In other words, when one considers the influence of nutrition on the direction of the curve of Quetelet. If we do this we observe that nutrition acts in the same, or at least in a similar manner, as selection. By increasing the food, the average and also the extremes move in the direction of the privileged individuals; by decreasing the food supply they move in that of the inferior ones.

But this point, however important it may be, has, as I have said before, been only imperfectly investigated.*

*In an exceedingly interesting book, entitled "Darwinism and Race Progress," J. B. Haycraft recently called attention to the desirability of a rational selection for 
Experience teaches us, that improvement in the food does not influence all qualities at the same time and to the same degree. But why one quality is more influenced by food than another, we do not know; perhaps the date of development of a character plays here an important part, and it is possible that better nutrition, begun at a later date, may still alter some qualities, while others have become almost unalterable.

It is also clear that nutrition cannot at once attain its full power, but only after some generations. For the seed matures in the mother plant, in the seed the young individual is developed, and passes through the first and most easily influenced stage of its life. Therefore, if we manure only at the time of sowing, we allow a very important part of plant life to pass uninfluenced. Only well nourished plants produce good seed, and the individual character of a plant certainly depends more on the nutrition in the preceding generation, or even the two or three preceding generations, than on the food given to the individual at the time of sowing.

One can probably go still further, and maintain that selection and nutrition are but the same factor, since the closer the relation becomes between nutrition and variability, the more will selection simply become the choice of the best nourished individual.

But I may not trespass on the field of investigation, neither do I dare to discuss the question, what influence nutrition has or might have, in the case of man, on the

man. He shows how the commonwealth nowadays pays far more attention than formerly to the existence of the less gifted ones, to physical characters (for instance, to susceptibility to disease), as well as to intellectual qualities. On the other hand, there exist numerous reasons why the higher classes contribute in a lesser degree to the multiplication of the race. This would, in course of time, lead to a general regression.

From this Haycraft deduces that only a careful selection will enable us to prevent this regression. Though this may be true, the present condition of our scientific knowledge is such, that we may justly look to the advancement of Science for other, less vigorous means, to obtain the same results.

But it requires considerable more study to be able to express ourselves with confidence on this subject. 
developmental tendencies of the individual. For at this time, our only concern is with the ideal, the ideal of the relation, which I endeavored to sketch, between experimental botanical studies and the great aim of science.

For it is the aim of all scientific investigation to contribute to the happiness of mankind. The greatest investigators have repeatedly expressed this. "Love for our work, love for our neighbor," exclaimed Berthelot, in his opening speech at the chemical congress held two years ago at Paris. And Pasteur's "Études sur la bière," undertaken immediately after the Franco-Prussian war, begins with: "L'idée de ces recherches m'a été inspirée par nos malheurs."

And the study of the phenomena of heredity can without doubt coöperate considerably to the attainment of this goal. 


\section{THE WILMERDING SCHOOL.}

To the Honorable Board of Regents

of the University of California:

\section{Gentlemen:-}

On October 12, 1897, the following resolution was passed by the Board:

"Resolved: That for the purpose of getting the best possible information obtainable concerning the establishment and equipment of the Wilmerding School, Regent A. S. HaLLidie be, and he is, hereby authorized and directed to visit Eastern cities and schools at his earliest possible convenience and that he report in writing to this Board the result of such visit, together with such recommendations as to him seem most wise concerning the proposed Wilmerding School."

In accordance therewith, and immediately after the completion of the Annual Budget of the University, on the third day of June, 1898, I left San Francisco, and visited schools kindred in character to the proposed Wilmerding, in many Eastern cities, and consulted a number of persons interested in such a school as Mr. Wilmerding desired to establish - "to teach boys trades fitting them to make a living with their hands, with little study and plenty of work."

Before leaving San Francisco, I submitted to several gentlemen identified with industrial pursuits in this State, the following questions, which I submit as a part of this report, with their replies. 


\section{QUERIES AS TO THE SCHOOL.}

1.-What trades should be taught? Please name in order of your preference.

H. J. Small, Superintendent Motive Power, Southern Pacific Railroad Company, Sacramento City: "Machinist, pattern-maker, boiler-maker, copper-smith, cabinet-maker, moulder, steam-fitter."

John F. MerriLl, Holbrook, Merrill \& Stetson, San Francisco: "All prominent and useful trades."

JAMES SpIERs, Fulton Engineering and Ship Building Works: "General mechanics, including pattern-making, machine-shop, foundry, blacksmith-shop and foundry, if possible, electrical machinery, carpenter trade, cabinetwork, farming work." (See notes A and B, pages 355-356.)

Asa R. Wells, Wells, Russell \& Company, Planing Mills, etc.: "Iron-work, electricians, architects, naval construction and engineering."

Geo. W. Dickie, Union Iron Works: "Trades being commercially practiced within a reasonable distance of the school. Working in iron and wood, cabinet-making, all kinds of brass-work, molding and casting, work in leather."

IRving M. Scotr: "All trades possible, especially wood and iron."

2.-Should other than practical instruction be given?

H. J. Small: "Yes."

John F. Merrill: "No."

JAMES SPIERS: "Yes."

Asa R. Wells: "Yes."

Geo. W. Dickie: "Practical instruction should be illustrative. Scientific instruction needed also."

IRving M. ScotT: "All instruction possible will add to efficiency." 
3.-If "Yes," please state the character and limit of such instruction.

H. J. Syall: "Pupils should be fully instructed in the theory of the trade he selects; also in the mathematies necessary for such trade."

JAMES SPIERS: "Scientific branches of education relating to the trade or industry should be given."

ASA R. Wells: "Technical studies and general information in the practical things of life."

GEo. W. DickIE: "Instruction in the different kinds of seientific knowledge that have a direct and practical bearing on industrial production."

IRving M. ScotT: "Theory and principles, customs and state of the art."

4 and 5.-To what extent should the pupils be taught the use of hand tools; of machines?

Replies from all- "Say to fullest extent; of machines, limited by funds available."

6.-Should instruction be free?

H. J. SmaLL: "Think it would be more appreciated if a charge was made."

John F. MerriLl: "No; if the pupil is able to pay even a small fee."

JAMES SPIERS: "By charging a small fee, I think better attention is secured; but provision should be made for those unable to pay." cases."

ASA R. Wells: "No, not entirely so, except in special

GEO. W. Dickie: "Depends on class of pupils to be reached. If children of poor parents, instruction should be free. I am afraid that the class of pupils most desirable to reach cannot be reached even by free instruction. Such 
a school could only reach those that most need its help by paying the pupils to attend."

Irving M. ScotT: "By no means. Teach the value of labor and earnings."

7.-Should the product of the pupils' work be put on the market ?

H. J. Small: "Think possibly it would be an advantage to place product on market, and solict custom work. It would have the effect to necessitate closer work and familiarize pupils with the commercial features of the trades."

JoHn F. MerRILL: "Think it would have to be. Trades unions might object."

JAMES SPIERS: "Yes."

AsA R. Wells: "Yes; in the spirit of emulation."

Geo. W. Dickie: "I should say certainly, if it can compete. The market itself would settle that question."

IRving M. ScOTT: "Work should consist of making articles now imported." (See "Remarks," pages 356-357.)

8.-When practicable should custom work be sought?

H. J. Small: (See answer to No. 7.)

JoHN F. Merrill: "I think not. That would make a direct competition with all factories and shops, and defeat the object for which the school is to be established."

JAMES SPIERS: "Yes. When an article forming a good subject for education is in the market. * * * * The proceeds from sales extends the school's usefulness."

ASA R. WELLS: "No; for the reason that trades unions would protest."

Geo. W. Dickie: "Yes, if practicable; which I doubt."

IRVING M. ScotT: "Yes. All work should be made with a view of being used to replace articles imported. With no interest, wear and tear, salaries or wages to pay, 
the school should be able to shut out the foreign article and build up a home product, by which some of your students will finally establish themselves in good paying enterprises, greatly to the benefit of the State. Kindergarten and show articles fill the community with sham artificers, and do not teach the mercantile value of cost of products."

\section{QUERIES AS TO THE PRINCIPAL.}

1.-Should the Principal be a practical mechanic?

Replies from all-"Yes"-except GEo. W. DickIE, who says: "In selecting a Principal, an effort should be made to get a man of wide experience in that kind of education, by securing the services of some one who has made a reputation in a similar institution. Where he comes from, where he has been taught, and what his age is, should not form factors; but simply what the man is, and what he has done in the line of work he is sought for."

\section{2.-In what branch?}

H. J. Small: "Machinist preferred."

John F. MerRILl: "Master mechanic, possessing general knowledge of different trades."

JAMES Spiers: "Mechanics, or general engineering." labor."

Asa R. Wells: "At the bench, or head of skilled

Geo. W. Dickie: (See answer to No. 1.)

IRving M. ScotT: "Many as possible."

3.-Should he have had experience in teaching?

H. J. Small: "It would be an advantage."

JoHN F. MerrILL: "Should be a practical man; well qualified to teach and explain intelligently."

JAMES SPIERS: "If possible; but not necessary." 
Asa R. Wells: "Yes; for teaching is an art as well as a qualification."

Geo. W. Dickie: (See answer to No. 1.)

Irving M. Scott: "Yes."

4.-Should he write and speak English correctly?

Replies from all-"Yes."

5.-Should he understand the higher branches of mathematics?

Replies from all-"Yes." "With some qualifications" (J. F. Merrill).

6.-Should he understand the theory of applied mechanies ?

Replies from all-"Yes."

7.-Should he be a good draughtsman?

H. J. Small, John F. Merrill, Geo. W. Dickie, and IRving M. ScotT reply "Yes."

JAMEs SpIERS and Asa R. Wells: "Not necessary; but should understand drawing."

8.-Should he be a good executive officer and administrator of affairs?

Replies from all-"Yes."

9.-Should he have a practical knowledge of bookkeeping ?

H. J. Small, Asa R. Wells, and Irving M. Scott: "Not necessary."

John F. Merrill and James Spiers: "Yes."

10.-Are there any reasons why the Principal should have resided in San Francisco or California for any length of time? 
Replies from all-"No"-except Irving M. Scott, who says: "Only that he may be familiar with western methods. High interest and wages, no iron, coal, or hardwood, are the problems in profits that must be worked out here on an entirely different basis than those used east of the Rocky Mountains."

\section{1. - What should be his age?}

John F. Merrill: "From 30 to 40 years."

JAMES SPIERS: "From 35 to 45 years."

Asa R. Wells: "Not over 65 years."

IRving M. Scotr: "Immaterial, so long as he is full of vigor mentally and physically."

QUERIES AS TO THE PUPIL.

1.-What class of boys should have the preference in admission?

H. J. Small: "There should be no restriction."

JoHn F. MerriLl: "Boys of limited means who are compelled to earn their living by manual labor and are anxious to learn a trade."

JAMES SPIERS: "Those who by their condition will be dependent on the use of their hands for a living."

ASA R. Wells: "Boys of good common school education, whose parents, if they have any, are citizens of the United States and live in California."

GEO. W. DiCKIE: "The class of boys should be from the families of working people, as those most likely to derive benefit from such a course of instruction."

IRving M. Scotr: "Those with an aptitude for mechanical training."

2.-At what age should they be admitted?

H. J. Small: "15 to 17 years." 
John F. Merrill: "15 to 17 years."

JAMES SPIERS: "16 to 18 years; with exceptions."

AsA R. WeLls: "15 to 17 years."

Geo. W. Dickie: "12 to 15 years. After three or four years in such a school, the boys would still have to serve an apprenticeship to any trade they might choose, and for that reason they should leave the school at from 17 to 18 years old."

IRving M. ScotT: "14 years; although much depends upon the boy's intelligence."

3.-On what qualifications? ( $a$ ), as to character; $(b)$, education; (c), physique.

H. J. SMall: "( $a$ ), good; (b), grammar school graduate."

JoHN F. Merrill: "( $a$ ), good moral character; $(b)$, grammar school education; (c), good robust physique."

JAMES SPIERS: "( $a$ ), good; $(b)$, fair primary education; (c), good healthy body."

AsA R. WeLls: "( $a$ ), good moral character and aptitude for mechanics. Should be excluded if addicted to intoxicants or eigarette smoking. (b), rudimentary; (c), unless crippled or deformed, his physique should not exclude him."

GEO. W. DickIE: "( $a$ ), read English language fluently, write clearly, and perform quickly the ordinary computations required in the trade he proposes to learn. The school should be responsible for his character, as he is too young to have formed any distinct character. $(b)$, included in $(a)$; $(c)$, rules should be broad enough to embrace any physical condition."

Irving M. SсоTт: "( $a$ ), honest and industrious; $(b)$, immaterial, aptness for trade selected more important. 
(See "Remarks," pages 356-357.) (c), free from hereditary or acquired disease."

4.- Should rudimentary instruction be given as a grounding before giving instruction in any special trade?

H. J. Small, John F. Merrill, James Spiers, and Geo. W. DickiE reply "Yes."

ASA R. Wells: "Would be well to a limited extent; but most of boys, 15 to 17 years, know the bent of their capabilities."

IRving M. Sсотт: "No; but should accompany instruction in trade."

5.-Should the Principal or the Pupil select the trade?

H. J. Small: "Inclination of pupil should be considered."

John F. Merrill: "The pupil, with advice of parents and principal."

JAMES SPIERS: "The pupil; but the principal may advise."

AsA R. WELLS: "The principal's judgment should have great weight; but the pupil should be reconciled, if consistent."

GEO. W. DICKIE: "If principal and pupil do not agree, pupil would not derive much benefit from remaining in school."

Irving M. Scott: "Pupil."

\section{JAMES SPIERS' Notes.}

A.-The words "little study and plenty of work" were evidently used by Mr. Wilmerding to express his desire that some "study" of a scientific character should be given; but that chief prominence should be given to the education 
of the hands to "work," so as to enable the scholar to earn a living for himself and his family by the intelligent use of his physical powers, to do which intelligently a certain amount of study (scientific) is necessary; which $\mathrm{Mr}$. Wilmerding desired the scholar should have.

B.-There are many industries requiring the work of the hand that it seems to me cannot come within the reach of a trade school; also that a trade school, with limited means, must confine itself to but few trades, in order to be efficient, so that the choice of trades or industry to be taught will be mostly a matter of expediency.

\section{IRVING M. SCOTT'S REMARKS.}

Referring to some of these queries, for instance those in regard to Principal, from Nos. 1 to 8 inclusive: it would be difficult to find all these qualities in the possession of one individual, although it would be of great advantage to do so.

In case of inability to find such a Principal, I should lay more stress upon No. 8 than any of the others, as a good executive officer and administrator of affairs will reinforce all the weak points, supply all necessary requirements, and make a complete and successful solution of the whole question, while he will fail in everything if he has not high executive qualities.

In reference to the query as to the age of the pupil: there should be no rigid rule as to age, which should be governed by the applicant, as some boys are better suited at twelve years than others are at fifteen, while others are not suited at all, and there are cases where boys should be admitted even as old as nineteen. But I am of the opinion, judging from the observation of a large number of boys for a great many years, that the character of the boy is formed between the age of thirteen and seventeen years; therefore, I am firmly convinced that the boy who is taught habits of industry during those years becomes a useful member of the 
community, and if he is not rigidly held to some occupation or calling, he is apt to become careless and one of the hoodlum class; consequently, I think it is of the utmost importance to teach boys habits of industry and learning from thirteen to seventeen years.

As to the education of a boy learning a trade: education is not absolutely necessary to make what is called a good workman; but it is absolutely indispensable in making what is called a leading or master workman, or a workman with executive ability. However, a good, honest boy with intelligence will learn as rapidly while learning his trade as at any other time, and will pick out the more solid and substantial facts that bear on the trade he is following, and therefore a lack of education, if the boy has natural ability, should not prevent him from being admitted.

As to your queries in regard to the school, Nos. 7 and 8: there is a very large amount of what is known as heavy hardware, which is made in the different prison factories, and under conditions which do not exist on this Coast, yet the conditions under which these articles are manufactured make the price; for instance, such articles as blacksmith's tongs, sledges, sash weights, barn-door hinges, lawn mowers, all of which could be easily manufactured in a technical school. They should be sold, not retailed, to wholesale dealers, and an effort made to quietly supply their trade and diminish their importations. This will injure no one on this Coast, and will get people in the habit of buying home products, which in the end will be of great benefit to the entire Coast.

February 25, 1898.

The Board, on November 17, 1896, passed the following resolution:

"Resolved: That in the matter of the Wilmerding School, the Board of Regents will, in accordance with the purpose of Mr. Wilmerding, establish a school wherein 
boys shall, as far as possible, be taught trades by practical work."

The resolution defined, as far as practicable, the character of the school to be founded and maintained under the Wilmerding bequest, hence, in my examinations, I confined myself to the class of schools coming nearest to the intentions of the above resolution.

Many of the manual training schools teach trades; but more incidentally than objectively. Many of them fit their pupils for the practical industries in a very thorough and complete manner, and from them are drawn the foremen, superintendents, engineers, architects, and mechanical experts, who are employed in great industrial enterprises, in charge of departments, or as consulting engineers, designers, etc.

Many of these I had already visited, but on this occasion I examined some of the more modern ones, such as the Armour Institute, the Lewis Institute, and the Chicago Manual Training School, of Chicago; the Cambridge Manual Training School, of Cambridge; the Manual Training School in Waltham, Massachusetts; the Hebrew Technical Institute, of New York; the Worcester Polytechnic Institute; and others.

Of trade schools, I visited the New York Trade School, founded in 1881, by Colonel Richard T. Auchmuty; the Baron de Hirsch Trade School, in New York, established 1894; the Master Builders' Mechanical Trade School, established 1895, in Philadelphia; and the Williamson Free School of Mechanical Trades, founded by Isaiah V. Williamson, of Philadelphia, 1888.

I have also taken the opportunity of talking with men closely connected with manual training, technical, and trade schools; with many manufacturers and mechanics, and with others engaged in the higher education.

My mission was to obtain information concerning the establishment and equipment of the Wilmerding School, 
so as to enable the Board to meet the wishes of Mr. Wilmerding, as understood by it; and, in carrying out the object of my visit, I found but three schools worthy of the name of trade schools, and whose functions are to teach boys trades fitting them to make a living with their hands, and which omit the higher branches demanded by technical and manual training schools.

While there seems to be a renewed interest in trade schools, and a general recognition of their value, there is by no means a unanimity of opinion as to how they should be conducted, in order to obtain the best and most economical results. The desired results, however, must be definitely determined in advance of the method of conducting the school.

All manual training schools are pretty much of the same type. Boys are taken at about twelve years of age. The mind and hands are trained together. The mind and intellect are carried educationally too far to make a contented and useful artisan and mechanic, and thus they differ from what we understand as a trade school, where the purpose is to turn out journeyman mechanics, artisans, and artificers.

Many of the manual training schools, such as the Armour Institute, in Chicago, and the Pratt Institute, in Brooklyn, teach special trades or vocations; but their main purposes are of a much higher educational order.

Numerous as are the manual training and technical schools in this country, they do not yet supply the demand for the class of educated men and women they graduate; which fact attests the excellence of their work and the great value of these schools, corroborated by the advanced position accorded by the civilized world to American engineers, constructors, etc.

But while the manual training school is more than its name implies, it is also more than we expect from a trade school. But to neglect the intellect in any school is utterly impossible, however much we may desire to confine 
ourselves to training the hands so as to make them useful in earning a living for their owner and his family in after life. Machines have become more useful than hands unintelligently directed, and more reliable, and the difference between some machines and some men is simply the intelligence of the man; and even then, in some cases, the difference does not appear to be very great.

The trade school, as we desire it, is to take the place of apprenticeship, as we understand it; and, in the substitution, to abolish the drudgery and waste of the latter, in the earnest and economical instruction of the former.

The need of such schools has long been admitted, and earnest workers have for years been trying to find a substitute for the old apprenticeship system, with results not entirely satisfactory.

I am not aware of a first-class shop in the country today that will take, except on probation, the graduates of a manual training or trade school. They have, in fact, to serve a sort of apprenticeship, when they enter the shop to work at the vise, lathe, or forge; but that long period of degradation and drudgery, which as a rule the old indentured apprentice had to serve, is abolished by means of these schools, never to be reinstated.

The secrets of the trade, so long and carefully guarded by the guilds of the middle ages with so much mystery, have been published to the world through these schools, remanded back to the common sense of careful manipulation, and found to be no secrets at all. A gentleman now at the head of the Williamson Trade School, who served his time as painter with his uncle, declared that in that trade there were no secrets; that careful instruction for six months in the manipulation of the brush, gave the art-the mixing of colors being by rule and observation.

While in his judgment six months are long enough to teach the essential rudiments of that trade, he is of opinion also that two years is not too long to teach the essential rudiments of such a trade as that of machinist, and that 
in both cases, the after experience in the shop, in contact with finished mechanics and the experience of varied work, is necessary to round out and complete the education of the mechanic. This is also the opinion of all the foremen and superintendents of shops with whom I have conversed on this subject. And the question of the day, in this connection is, can this condition be mitigated or remedied?

A study of the distinct methods employed by two trade schools, the New York and the Williamson, may throw some light on the question.

\section{NEW YORK TRADE SCHOOL.}

The purpose of the New York Trade School "is to give instruction to young men in certain trades, and to enable young men already in those trades to improve themselves."

The system of instruction here was originated by Colonel Richard Tylden Auchmuty, under which "both the practical and theoretical branches of the trade are taught, so that not only is skill quickly acquired, but the scientific principles which underlie the work are also studied."

Under this system young men have been enabled to learn the science and practice of certain trades "expeditiously and economically, leaving speed of execution and experience to be acquired at real work after leaving school."

Each student is under the direct care and investigation of a skilled and experienced mechanic, and careful explanation is made of every step in the course. The student is shown how to hold his tools and how each piece of work should be done.

An opportunity is given the young man to determine if he has an aptitude for a certain trade, so that he may discover his unfitness promptly, and thus avoid the serious defect in the old apprenticeship system, where a boy was bound for years to a trade, fit or unfit, like or dislike.

Instruction is given day and evening, both or either, as the case may demand. 
The day class, as a rule, begins at 8:00 a.m. and closes at 4:00 p.m.; the evening class, 7:00 to $9: 30$.

Instruction is intensive and the term short, four to five and one-half months. Some few take a second term.

The age for admission is from 17 to 24 , and it is the opinion of those best able to judge, that none should be admitted younger than 16 , and that they should possess a good physique, in order to withstand the physical strain due to the labor, even under careful supervision.

Fees sufficient only to cover the cost of material are made, and vary from $\$ 6.00$ to $\$ 16.00$ per term for the evening classes, and from $\$ 25.00$ to $\$ 40.00$ per term for the day classes.

There is a students' dormitory, where rooms are rented for $\$ 2.00$ per week.

In this school nothing is made to be sold. No academic work is done; neither reading, writing, or arithmetic is taught, except what is incidentally brought out during the lectures or explanation as the work progresses; no machines are used, except a bender in the sheet-iron department.

The school has been designated by the City of New York as the Civil Service Examining Board for Candidates in Mechanical Work, and I saw about twenty men, all ages, cutting stone, who were candidates, as masons, for work on city buildings.

The attendance of young men has averaged over 500 annually during the past five years, and since the school was founded 6,230 young men have attended the school. Applications are in excess of the capacity of the school, which is located on First Avenue, between 67th and 68th Streets, New York. The buildings are partly one story and partly three stories. The ground space occupied by the buildings is 58,040 square feet. Some of these buildings were constructed by the students, and in the vicinity are four-story brick buildings also constructed by them. 
The trades taught in this school include bricklaying, plastering, plumbing, electrical work, carpentering, house painting, stone-cutting, fresco painting, blacksmithing, printing, sign painting, sheet-metal cornice work, steam and hot water fitting, and drawing.

The trades unions accept the graduates as juniors, but require that they shall serve two years with a master mechanic, and shall be at least 21 years old before they rank as journeymen and get full wages.

There are trade school committees, consisting of master mechanics, who inspect the work done by the students.

The New York Trade School used to grant diplomas, but now grants certificates. The New York State law, recently passed, prohibits the granting of diplomas, except to those who have received a full collegiate course.

Horse-shoeing was formerly taught, in connection with veterinary science, in the school; but the State passed a law, at the instigation of the horse-shoers, requiring every young man to serve an apprenticeship before practicing his art.

The New York Trade School had the benefit of Colonel Auchmuty's experience and personal direction during his life, and he lived to see his plan a success, when failure had been predicted.

The master builders of Philadelphia, through a committee, examined the New York Trade School, and have started in Philadelphia the Master Builders' Mechanical Trade School. It is so far only an evening school, and was started in 1890 , on the plan of the New York school.

The age for admission is between 16 and 21 years.

The charge for the term is $\$ 27.00$, and the term is nine months.

Five evenings per week are required, two of which are occupied in actual work, and three in theoretical and scientific instruction.

"It is conducted on the principle of teaching thoroughly how work should be done, and leaving the quickness that 
is required of a first-class mechanic to be acquired at real work after quitting the school."

Trades taught here are carpentry, bricklaying, plastering, stone-cutting, blacksmithing, painting, and plumbing.

\section{WILLIAMSON FREE SCHOOL OF MECHANICAL TRADES.}

The Williamson Free School of Mechanical Trades occupies a different place from the New York Trade School. It was founded by Isaiah V. Williamson, of Philadelphia, under a deed of trust, dated December first, 1888, and was opened October 20,1891; it has consequently been in operation over six years.

It is located about sixteen miles from Philadelphia, on a very pretty tract of 200 acres, and includes twenty buildings.

The deed of trust is very specific in its instructions, and among other things, it provides that all scholars admitted to the school shall be bound as indentured apprentices to the trustees for such periods as the trustees may provide; but no indenture shall be for less than three years, nor extend beyond the minority of the scholar.

Scholars shall be fed with good wholesome food, plainly, neatly, and carefully clad, and decently and fitly housed and lodged.

If not properly educated, they shall be educated-a specification of which is given,-but all with the end of being useful to them in the trade they are to learn, bearing in mind "the fact that the main object I have in view is to train young men to mechanical trades, so that they may earn their own living." * * * * "Any higher or advanced knowledge which might render them dissatisfied with or unfit for their employments is unnecessary and may be disadvantageous. I expressly direct that each and every scholar shall be compelled to learn and be thoroughly instructed in one good mechanical trade, so that when they leave the school, on the completion of their indentures, they may be able to support themselves by the labor of 
their own hands." And then the trades to be taught are enumerated. Proselytism and favoritism are prohibited, and it is expressly directed that each scholar shall be taught to speak the truth at all times. Mr. Williamson says: "I desire to have impressed on every scholar and inmate of the school, that in this country every able-bodied healthy young man, who has learned a good mechanical trade, and is truthful, honest, frugal, temperate, and industrious, is certain to succeed in life and to become an useful and respected member of society."

I have quoted thus from the deed of trust, as the language will convey more of the spirit of the founder, and better than I could express.

The amount of the endowment exceeded $\$ 2,000,000$. The amount in the fund after purchasing the site, erecting and equipping building, etc., is $\$ 1,500,000$. Scholars are admitted after a scholastic examination covering reading, writing, spelling, arithmetic, including fractions and weights and measures, geography, United States history, composition and language. They must be not younger than 16, or older than 18, and must be natives of the United States. "And no one is accepted who is not able-bodied, intelligent, healthy, and possessed of a natural aptitude and liking for mechanical pursuits," and of good moral character. $\mathrm{He}$ must be provided with proper clothing when he enters the school, after which he is taken care of.

Each scholar is given a preparatory course in woodworking and mechanical drawing, with studies in the schoolroom extending six months. At the end of this period he is placed at one of the five following trades, the selection of which is made by the trustees: carpentry, pattern or cabinet-making, bricklaying, including range-furnace and boiler setting, machine trade, in all its branches, steam and electrical engineering, steam-fitting, etc.

The school and shops are in session eight hours daily, on five days in the week, and four hours on Saturday; about four hours class-room and four hours shop during 
the first year; the time in the shops gradually increasing towards the end of the apprenticeship.

The school term continues the whole year.

There is ample provision for recreation.

The discipline is quite strict. Scholars rise at 5:45, bathe, dress, and place their rooms in order. The school is divided into "families" of twenty-four, over which presides a mother, or matron, who is responsible for the boys' behavior.

I never saw a better looking set of boys. They were at dinner part of the time I was there. I dined in the same room with them, and they passed in review before me as they filed out of the dining-room.

I found most excellent work, executed by the pupils, and some of the buildings on the grounds had been erected by them.

The shops are well equipped with modern tools and machines.

The young men who graduate from this school are probably better prepared to commence work as journeymen than the graduates from any similar school; but the shops and the trades unions require that they shall have two years' actual experience in the shop, among experienced mechanics, before being admitted as journeymen and receiving their wages. They are, however, able to earn from $\$ 6.00$ to $\$ 9.00$ per week at the outset.

In talking with the President, Mr. John H. Shrigley, he expressed the opinion that the usefulness of the school would be very much enlarged if the "maternal" character of the school was removed, and if the school was nearer Philadelphia or in the eity. He doubted the wisdom of making everything absolutely free.

In examining the financial report for 1897 , of the total expenditures, $\$ 58,444.36$, there were spent for board, lodging, and elothing pupils, and for house expenses, $\$ 33,619.82$; for common school education, $\$ 4,349.62$; for care, etc., of lands, $\$ 2,873.14$-leaving for the mechanical 
education of 175 pupils, $\$ 17,601.78$, about $\$ 100$ per capita. Total expenses, per pupil, is $\$ 333.97$ per annum.

\section{BARON DE HIRSCH TRADE SCHOOL.}

The Baron de Hirsch Trade School was founded by Baron de Hirsch, to aid the sons of poor Russian and Roumanian Jews. It is located in the heart of New York, on 9th Street, not far from the Cooper Institute, and occupies at present a building leased from the Hebrew Technical Institute. The work of this school is based upon the New York Trade School, and under the management of the present superintendent, Mr. J. E. G. Yalden, is eminently successful.

There is no special condition for entrance, except age, healthy body, intelligence, and aptitude, and two or three weeks proves the boy's value. There are no fees or charges of any kind, and during the term each boy makes a kit of tools, which he is allowed to take with him. There is a disposition to look for a job before their time is out.

The aim of the school is:

1. - To teach a boy as quickly as possible the fundamental principles of a trade, with such a knowledge of figuring and mechanical drawing as will be indispensable to him in his chosen line of work.

2. -To teach him to do well just what is required of the class of help whose place he is fitted by age and condition to fill.

3.-To teach a boy unquestioning obedience.

The boys are received not younger than 16. Many of them cannot speak a word of English, and have received little or no training from their parents, and much of their instruction is in pantomime.

The term is five and one-half months. The superintendent says that this length of course is sufficient to accomplish the aims set forth, and thinks that additional 
time would be wasted, and had better be spent in the shops where they are to do actual work and where they will be brought in contact with other workmen.

Six classes have graduated in all 208, of which 31 were carpenters, 11 wood-turners, 1 house painter, 49 sign painters, 63 plumbers, 53 machinists. Average wages earned at commencement of employment, on leaving school, per week, $\$ 4.66$. This is, of course, increased as they get experience, until they earn from $\$ 9.00$ to $\$ 16.00$ per week.

Last year it cost $\$ 169.60$ to graduate a pupil.

Formerly there used to be a good deal of trouble with the scholars; but since discipline has been enforced, everything moves smoothly. Mr. Yalden is an educated mana Christian.

The report of the work done in the school during the past two years has been so satisfactory to the Baroness de Hirsch de Gercuth, that she sent on $\$ 150,000$ to erect a new building, which is now nearly completed on 64th Street, between 2nd and 3rd Avenues. And, at the suggestion of the trustees, the benefits of the school is to be extended to Jewish youths of all nations.

\section{PHILADELPHIA TEXTILE SCHOOL.}

The Philadelphia Textile School, which I also visited, is devoted to spinning and weaving cotton, wool, and silk. It is fully equipped with all the modern machinery, and treats the material in all details, from the raw material to the finished article.

The School of Applied Arts is in the same building, and teaches drawing, painting, modelling, designing, etc. The building occupies a space 200 by 396 -about the size of the block selected for the Wilmerding School.

In my judgment, the existing examples to be studied are the New York Trade School, the Baron de Hirsch School, and the Master Builders' Mechanical Trade School, 
as one type; and the Williamson Free School of Mechanical Trades, as the other. And whoever is selected to take charge of the Wilmerding School should be given time, say two or three months, to carefully examine into and study the workings and results of these schools, to note the details of construction of the buildings and their equipment. He should then make a careful study of the conditions on the Pacific Coast generally, and of California and San Francisco particularly, and prepare his scheme of instruction, the plan of building, and their equipment.

If the Wilmerding School is planned somewhat after the Auchmuty system, no expensive machinery will be required; if after the Williamson plan, a large investment in machines and apparatus will be necessary.

The man to take charge of the Wilmerding School should be an educated mechanic, with ability to teach. $\mathrm{He}$ should have had experience in some such institution as the proposed Wilmerding School, and have administrative ability.

I do not think we would care to carry out the Williamson plan; and the Auchmuty system probably should be modified to suit the conditions which exist here, and the character of the trades to be taught.

It must be borne in mind that no school has yet succeeded in turning out a mechanic ready to take up the work of a shop. This is acquired, however, in a short time after leaving the school.

It has, however, been proved to the satisfaction of those interested, that a young man, by steady and assiduous work, by careful, concentrated, and intelligent attention to instruction given in an earnest, clear, and simple manner, by teachers who know more than they teach, and who are able to impart instruction from experience based on broad lines, can be taught the intricacies of manipulation in many trades in five and one-half months. There are trades, however, that will take three such terms, and the length of 
time should be graduated to the character of the work to be taught.

While in the school the pupils are more than anxious to learn, and consequently things are kept under somewhat high pressure by general consent. The age of the youths, $16 \mathrm{up}$, and the good bodily health necessary for the physical labor required in such a school, enable them to endure eight hours work for these short terms without mental and physical fatigue; the fatigue, in fact, is with the teachers.

I have conferred very freely with men in and out of these schools in relation to the question-SHALL ARTICLES BE MADE IN THE SCHOOL TO BE SOLD? and the verdict is generally in the negative.

The Worcester Polytechnic Institute supports the commercial view, and makes it part of the shop system. Quite a staff-thirty, I believe-of skilled workmen is employed throughout the year. Contracts are taken and executed, and the young men get their training in the shop, working at stated hours with and under the direction of these skilled mechanics. It is doubtful if the best results are attained in this way, for if the young men without experience have a chance at the work, the work must suffer, and the commercial value of the same reduced.

If the commercial aspect has to be considered at all, it must be subordinate to the educational. Whichever plan is carried on, the other will suffer. With the commercial, the temptation is to keep a youth at work on that which he does best and quickest, and thus to limit the field of his experience; per contra, if a thing is made and put on the market, its commercial value is fixed, and perhaps the ambition of the youth is aroused.

Shall the Wilmerding School Be Free? The opinion of the three schools I have referred to at considerable length, is against free instruction, and this is the opinion of the gentlemen in California whose views are given on pages 348 to 357 , and of nearly all those connected with the management of manual training schools with whom I have conferred. 
In trade schools there is a great deal of material destroyed and wasted, and the New York Trade School charges are to cover the cost of the same, and no more.

A great deal depends on the management of the school, but as much also on the convenience and healthfulness of location, adaptability of buildings, and cheerfulness of surroundings.

The proper sanitary condition of the neighborhood must be assured; of this there must be no doubt.

The immediate surroundings of the different work shops should be in accord with the trade being taught. Everything should be done to impress the student with that one idea-concentration of mind is essential to success.

A due regard to existing schools similar in purpose, would suggest that the course of study in the Wilmerding School should not duplicate that of the Lick or Cogswell, but that there should be coöperation between them. San Francisco is not a large city, and the active work of three such schools, and possibly four (the Lux), can be made of immense benefit to the people, if wisely and economically administered under one directing influence.

I submit, herewith, printed pamphlets, catalogues, and other papers in connection with various trade and similar schools.

A. S. Hallidie.

San Francisco, California, August 1, 1898. 


\section{SCIENTIFIC SOCIETIES.}

\section{PHILOSOPHICAL UNION.}

The Philosophical Union met twice during the month of August to hear Professor James of Harvard University. The first meeting was held in the Harmon Gymnasium, Friday evening, August 26. The building was packed, a conservative estimate placing the number present at 1000 . The address is now published as the leading article of this issue of The University Chronicle.

On Tuesday, August 30, the Union met again, this time in special session in the Philosophy Building. Professor James reviewed the papers read before the Union during the past year. These papers had been, in the main, critical examinations of Professor James' philosophical opinions as expressed in his recent book, "The Will to Believe and Other Essays in Popular Philosophy." This volume, as the author says in the preface, expresses "a tolerably definite philosophical attitude in a very untechnical way," an attitude which he calls "that of radical empiricism." It is an empiricism because "it is contented to regard its most assured conclusions concerning matters of fact as hypotheses liable to modification;" and it is radical "because it treats the doctrine of monism itself as an hypothesis, and, unlike so much of the half-way empirieism that is current under the name of positivism or agnosticism or scientific naturalism, it does not dogmatically affirm monism as something with which all experience has got to square." "Absolute unity, in spite of brilliant dashes in its direction, still remains undiscovered." "Something-call it fate, chance, freedom, spontaneity, the devil, what you like-is still wrong, and other and outside and unincluded," "and there may be in the whole universe no 
one point of view extant from which this would not be found to be the case."

The papers read during the year had been for the most part an attack upon this position, although some of them were directed to the pointing out of incompleteness in statement rather than of inadequacy in fundamental conception. Those of the former class Professor James treated very sympathetically, acknowledging the lack of thoroughness in the presentation of his views on many points. He admitted that in his essay, "Reflex Action and Theism," he should not have maintained that theism brings into play all the activities of man, but only all the nobler, higher forms of human activity, and that thus a preference for theism presupposes a scale of values.

Against the papers attacking his fundamental position he maintained that he had been misunderstood and misrepresented when it was claimed by his critics that he believed in things-in-themselves apart from consciousness. His sensationalism is idealistic, even though this idealism is merely a working hypothesis. He also contended that, in his essay, "Is Life Worth Living?" he had not attempted to prove that life in general is worth living, but merely to show how it can be made worth living in any individual case. Against a criticism of his essay "On Some Hegelisms," he said that even though in a sense it could be asserted that there is an identity underlying all differences present in any single consciousness, still the absolute difference of the contents lying in different consciousnesses remains untouched.

These two meetings were significant as being the first in which a prominent empirical philosopher has spoken before the Union. Heretofore anti-empiricists have had things much their own way. Although the empiristic school has always had its defenders in the Union, the large majority of the members who take part in the meetings are apriorists, and before Professor James came philosophers who have been brought to Berkeley by the Union to 
address it have been idealists of the Hegelian type. The presentation of empiricism by Professor James, therefore, led to a lively discussion.

Professor John Dewey, of the University of Chicago, has been invited to address the Union next May, and the year will be devoted to the study of his works, especially of his syllabus, "The Study of Ethics."

\section{THE GREEK CLUB.}

The University of California Greek Club is an organization of instructors and graduate students, for the purpose of mutual study and criticism. In its general plan it is similar to the famous New York Greek Club, which has been for more than twenty years an important factor in the scholarly life of the metropolis, having included in its membership such well-known men as Edmund Clarence Stedman, Howard Crosby, Henry Drisler, Charlton Lewis, and many others of scarcely less note. The essential features of the New York Club are translation and free criticism, and these have been adopted as the basis of work in the Club here. The Club meets every Saturday evening at eight o'clock and adjourns at ten. One of the members reads a carefully prepared translation of a passage (perhaps eight or ten pages) from the work which has been selected for the year's study. The other members then offer their criticisms, and join in a general discussion of any questions which happen to be raised. There are no officers, but the reader of the evening acts as temporary chairman.

The Greek Club was organized in August 1897, and held thirty-four meetings during the last academic year, reading and discussing six plays of Aristophanes. This year the study of Plutarch's Lives has been taken up. The character of the work (and of the place of meeting) makes it necessary to limit the membership to a small number. Of the present members five are University officers (in three different departments), one is a High School teacher, and three are graduate students. 


\section{CURRENT NOTES.}

At a meeting of the Council, held August 26th, the Recorder presented the following table showing the growth of the undergraduate department of the University during the last eight years:

\begin{tabular}{r||r|r|r|r|r|r|r|r|r|r}
\hline \hline & 1891 & 1892 & 1893 & 1894 & 1895 & 1896 & 1897 & 1898 \\
\hline Applications to date................. & 252 & 271 & 357 & 517 & 556 & 610 & 500 & 546 \\
Withdrawn or rejected ...... & 15 & 20 & 51 & 77 & 120 & 123 & 60 & 34 \\
Pending................................ & 45 & 8 & 3 & 21 & 4 & 6 & 25 & 64 \\
Admitted: & & & & & & & & \\
1.-Freshmen (Regular) & 146 & 178 & 238 & 339 & 345 & 326 & 302 & 333 \\
2.-Freshmen (Limited) & 10 & 19 & 20 & 24 & 17 & 71 & 45 & 41 \\
3.-Special Students ...... & 36 & 46 & 45 & 56 & 70 & 84 & 68 & 74 \\
\hline Total Admitted.......... & 192 & 243 & 303 & 419 & 432 & 481 & 415 & 448 \\
\hline \hline
\end{tabular}

Since then there has been a number of new applications and admissions, so that the incoming class will undoubtedly be the largest in the history of the University. The following table, which takes account of Regular and Limited Students only, shows the growth of the different colleges:

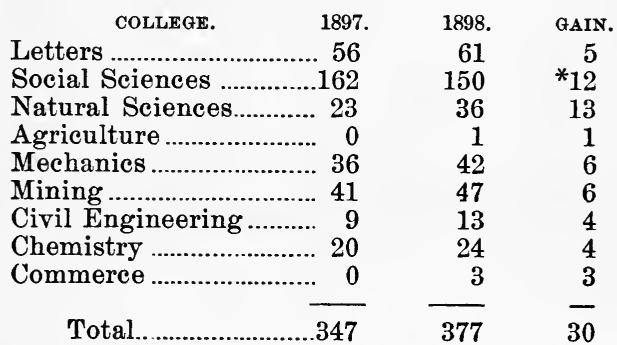

Thus far there is indicated a slight falling off in the number of Graduate students, 60 having been admitted as against 55 in 1896 and 71 in 1897. 
The number entering from the accredited High Schools is as follows: Alameda, twelve; Alameda Union No. 2 (Centreville), six; Alameda Union No. 3 (Haywards), four; Alameda University Academy, four; Arcata, one; Armijo (Suisun), two; Belmont, seven; Berkeley, fifty; Boone's (Berkeley), eleven; California School of Mechanical Arts (San Francisco), four; Chico State Normal, three; Colusa, one; Dixon, three; Esparto, one; Fresno, five; Hanford, three; Miss Head's (Berkeley), three; Healdsburg, five; Hoitt's (Burlingame), one; Los Angeles, eight; Los Angeles State Normal, seven; Lowell (San Francisco), thirty-two; Marysville, one; Mendocino, three; Merced, two; Mills College(Preparatory Department), one; Modesto, two; Monrovia, one; Mt. Tamalpais Military Academy (San Rafael), one; Nevada City, one; Oakdale, one; Oakland, twenty-eight; Pasadena, four: Petaluma, two; Polytechnic (San Francisco), two; Pomona, two; Redlands, five; Riverside, six; Sacramento, fifteen; San Bernardino, three; San Diego, six; San Francisco Girls', fourteen; San José State Normal, two; San Luis Obispo, seven; San Rafael, two; Santa Ana, one; Santa Barbara City High, seven; Santa Barbara Collegiate School, one; Santa Cruz, three; Santa Maria, one; Santa Rosa, six; Southwest Institute (San Diego), two; St. Matthew's (San Mateo), three; Stockton, three; Trinity (San Francisco), one; Ukiah, four; Vacaville, three; Vallejo, two; Ventura, two; Visalia, seven: Miss West's (San Francisco), two; and Woodland, four.

The following table shows the enrollment in the Summer School Courses in Chemistry and Physics since the beginning of Summer School work:

$\begin{array}{lcccccccc} & 1891 & 1892 & 1893 & 1894 & 1895 & 1896 & 1897 & 1898 \\ \text { Chemistry .... } & 6 & 25 & 16 & 19 & 37 & 56 & 59 & 53 \\ \text { Physics........... } & & 15 & 20 & & 30 & 51 & 53 & 50\end{array}$


At a meeting of the Academic Council held August 26th, the Committee on the Examination of Schools recommended the accrediting of the following schools for the year 1897-8:

sCHOOL.

SUBJECTS IN WHICH ACCREDITED.

Alameda Co. Union High School No. 2, Centreville, 1, 3, 4, 5, 6, 7, 8, $9,10,11,12 a^{1}, 12 a^{2}, 12 a^{3}, 12 b, 12 c, 12 d, 13,14$.

Alameda Co. Union High School No. 3, Haywards, 1, 3, 4, 5, 6, 7, 8, $9,10,11,12 a, 13$.

Alameda High School, 1, 3, 4, 5, 6, 7, 8, 9, 10, 11, 12a $12 a^{2}, 12 b, 13$, $14,15 b$.

Alameda University Academy, $1,3,4,5,6,7,8,9,10,11,12 a^{1}, 12 a^{2}$, $12 b, 14$.

Arcata Union High School, $1 a, 3,4,5,10,11,12 a^{1}, 12 a^{2}, 12 b, 13,14$. Armijo Union High School, Suisun, 1, 3, 4, 5, 6, 7a, 10, 11, 12a $a^{1}, 12 b$, $12 c, 13,14$.

Belmont School, 1, 3, 4, 5, 6, 7, 8, 9, 10, 11, $12 a^{1}, 12 a^{2}, 12 a^{3}, 12 b, 13$, $14,15 a, 15 b$.

Berkeley High School, 1, 3, 4, 5, 6a, 6b, 7a, 8, 9, 10, 11, 12a, $12 a^{2}$, $12 b, 13,14,15$.

Boone's University School, Berkeley, 1, 3, 4, 5, 6, 7, 11, 12a $1212,14$. California School of Mechanical Arts, San Francisco, 1, 3, 4, 5, 10, 11, $12 a^{1}, 12 a^{2}, 12 b, 13,14$.

Citrus Union High School, Azusa, 3, 4, 5, 6, 7, 8, 10, 12a $, 12 a^{2}, 12 b$, $13,14$.

Colusa High School, 1a, 3, 4, 5, 6, 7a $a^{1}, 7 a^{2}, 10,11,12 b, 13,14$.

Coronado Union High School, 1, 3, 4, 5, 6, 7, 10, 11, 12b, 13, 14.

Dixon Union High School, 1, 3, 4, 5, 6, 7a, 10, 11, 12a $, 12 a^{2}, 13,14$. Escondido High School, 1, 3, 4, 5, 6, 7b, 10, 12b, 12c, 12d, 13, 14 .

Esparto Union High School, $1 a, 3,4,5,6,7 a, 10,11,12 a^{1}, 12 a^{3}, 12 b$, $13,14$.

Fresno High School, 1, 3, 4, 5, 6, 7, 10, 11, $12 a^{1}, 12 a^{2}, 12 b, 13,14$.

Fullerton Union High School, 1, 3, 4, 5, 6, 10, 12a $12 a^{3}, 12 b, 13$.

Hanford Union High School, 1, 3, 4, 5, 6, 7a, 10, 11, 12a $, 12 a^{2}, 12 b$, $12 c, 13,14$.

Miss Head's Preparatory School, Berkeley, 1, 3, 4, 5, 6, $7 a^{1}, 7 a^{2}, 7 a^{3}$, $8,9,10,11,12 a^{1}, 13,14,15$.

Healdsburg High School, 1, 3, 4, 5, 6a, 6b, 10, 11, 12b, 13, 14.

Hoitt's School, Burlingame, $1 a, 3,4,5,6 a, 6 b, 7 a^{1}, 10,12 a^{1}, 12 a^{2}, 12 b$, $13,15$.

Miss Horton's School, Oakland, 1, 3, 4, 5, 6, 7, 8, 9, 10, 13, 14, 15.

Irving Institute, San Francisco, 1, 3, 4, 5, 10, 12b, 13, 14, $15 a$.

Kern Co. High School, Bakersfield, 1a, 3, 4, 5, 6, 10, 11, 12a $a^{1} 12 a^{2}$ $12 b, 13,14$. 
The matriculation subjects are as follows: 1a. English, elementary; 1b. English Composition; 3. Algebra, through Quadratics; 4. Plane Geometry; 5. Government of the United States; 6a. Caesar's Gallic War; 6b. Cicero's Orations; 6c. Latin Composition, elementary; $7 a^{1}$. Cicero's Orations; $7 a^{2}$. Virgil's Aneid; $7 a^{3}$. Latin at sight; $7 a^{4}$. Prosody; 7b. Latin Composition, advanced; 8. Greek Grammar and Xenophon; $9 a^{1}$. Xenophon's Anabasis; $9 a^{2}$. Greek at sight; $9 a^{3}$. Greek Composition; 9b. Homer's Iliad; 10a. Greek History; 10b. Roman History; 11. Physics; $12 a^{1}$. Solid Geometry; $12 a^{2}$. Plane Trigonometry; $12 a^{3}$. Advanced Algebra, Part I; $12 a^{4}$. Advanced Algebra, Part II; 12b. Chemistry; 12c. Botany; 12d. Zoölogy; 13. Mediæval and Modern History; 14. English, advanced; 15a. French; 15b. German; 16. Free-hand Drawing.

The teaching force of the Colleges at Berkeley has been augmented this term by the following additions: George Davidson, Ph.D., Sc.D. (Univ. Pa.), Professor of Geography; S. D. Townley, Sc.D. (Michigan), Instructor in Practical Astronomy; R. S. Norris, Ph.D., Instructor in Chemistry; J. T. Allen, Ph.D. (Yale), Instructor in Greek and Classical Archæology; T. W. Page, Ph.D. (Leipzig), Instructor in History and Economics; H. M. Hopkins, Ph.D. (Harvard), Instructor in Latin; and E. J. Wilczynski, Ph.D. (Berlin), Instructor in Mathematics. Professors Gayley and Lawson and Instructor Drew have also resumed work after prolonged absences.

At a meeting of the Regents held April 12, 1898, Curtis H. Lindley, who was a student of this University in the class of '74, author of "A Treatise on the American Law relating to Mines and Mineral Lands," was appointed Honorary Professor of the Law of Mines and Water. On September 7th Professor Lindley began a course of lectures on The Public Lands, Mines, and Water. Being prevented by mining business from lecturing on September 
21st, he sent as a substitute Dr. Rossiter W. Raymond, of New York City, United States Commissioner of Mining Statistics from 1868 to 1876 and Secretary of the American Institute of Mining Engineers since 1884, who lectured on the origin of the United States Mining Law.

Arrangements having been made by the President of the University to have the course in Modern Astronomy given jointly by the Lick Astronomical Department and the Department of Astronomy at Berkeley, Director Keeler has announced the following lectures at Berkeley during the second term of 1898-9 by members of the staff of the Lick Observatory: Director James E. Keeler, The Methods of Astrophysical Research, The Classification of the Stars; Astronomer W. W. Campbell, Spectographic Determinations of Stellar Motions, Some Observations bearing on the Question of Sidereal Evolution; Astronomer R. H. Tucker, Astronomy of Precision: Aims, Astronomy of Precision: Methods; Astronomer W. J. Hussey, The Surface Features of Mars, A Review of the Methods and Results of Double Star Astronomy.

During the first term of 1898-99, the following University Extension courses, free to the public, will be given in the Mark Hopkins Institute of Art, San Francisco:

Six Lectures on China, by Professor John Fryer: The Government and Laws of China, Education in China, The Productions and Commerce of China, Home and Social Life in China, The War between China and Japan, and The Outlook for China.

Mathematics: six lectures by Associate Professor Haskell on The Theory of Equations, based on the Theory of Substitutions.

GREEK : six readings, with translation and comment, from the first half of the Odyssey of Homer, by Associate Professor Flagg.

Six Lectures on International Law, by Assistant Professor Hengstler: The United States as a Member of the Family of Nations. -Its Traditional Attitude, The United States as a Member of the Nations.-Recent Indications of a Change of Attitude, The United States as a Member of the Family of Nations.-What should be its Future Attitude?, The Principle of Intervention, Recent and Proposed Changes in the Laws of War, and International Domicil and Citizenship. 
The striking list of men editing the Psychological Review, or co-operating with the editors, furnishes an interesting indication of the union of the larger universities in their higher work. This list is as follows: J. McKeen Cattell, Columbia University; J. Mark Baldwin, Princeton University; Alfred Binet, Êcole des Hautes-Études, Paris; John Dewey, H. H. Donaldson, University of Chicago; G. S. Fullerton, University of Pennsylvania; G. H. Howison, University of California; Joseph Jastrow, University of Wisconsin; G. T. Ladd, Yale University; Hugo Münsterberg, Harvard University; M. Allen Starr, College of Physicians and Surgeons, New York; Carl Stumpf, University, Berlin; James Sully, University College, London.

Professor George Bruce Halstead, Professor of Mathematics in the University of Texas, visited the University on his way home from the Orient, and delivered two lectures; one on Japan, on Thursday evening, September 8th, before the Science Association; and one on NonEuclidean Mathematics, on Saturday morning, September 11th, before the class in Absolute Geometry.

On September 23, Professor Carl Schroeter, Professor of Botany in the Technical University of Zurich, visited the University on his way around the world and inspected the work of the Department of Agriculture. 




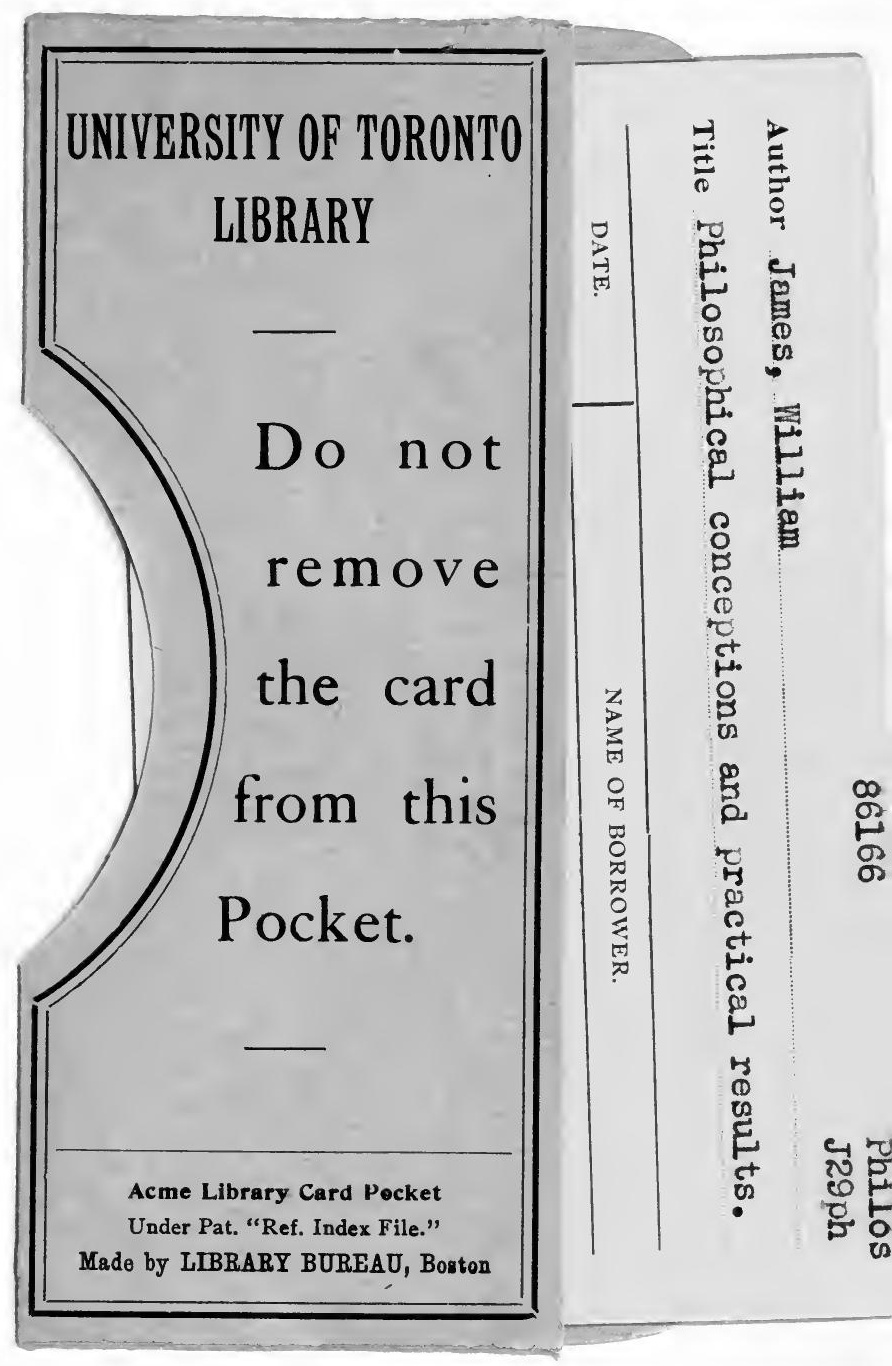


